\title{
Optimality-based model of phytoplankton growth and diazotrophy
}

\author{
Markus Pahlow*, Heiner Dietze, Andreas Oschlies \\ GEOMAR Helmholtz Centre for Ocean Research Kiel, Düsternbrooker Weg 20, 24105 Kiel, Germany
}

\begin{abstract}
The notion that excess phosphorus (P) and high irradiance favour pelagic diazotrophy is difficult to reconcile with diazotroph behaviour in laboratory experiments and also with the observed distribution of $\mathrm{N}_{2}$-fixing Trichodesmium, e.g. in the relatively nitrogen (N)-rich North Atlantic Ocean. Nevertheless, this view currently provides the stateof-the-art framework to understand both past dynamics and future evolution of the oceanic fixed $\mathrm{N}$ inventory. In an attempt to provide a consistent theoretical underpinning for marine autotrophic $\mathrm{N}_{2}$ fixation we derive controls of diazotrophy from an optimalitybased model that accounts for phytoplankton growth and $\mathrm{N}_{2}$ fixation. Our approach differs from existing work in that conditions favourable for diazotrophy are not prescribed but emerge, indirectly, from trade-offs among energy and cellular resource requirements for the acquisition of $\mathrm{P}, \mathrm{N}$, and carbon. Our model reproduces laboratory data for a range of ordinary phytoplankton species and Trichodesmium. The model predicts that (1) the optimal strategy for facultative diazotrophy is switching between $\mathrm{N}_{2}$ fixation and using dissolved inorganic nitrogen (DIN) at a threshold DIN concentration; (2) oligotrophy, especially in P and under high light, favours diazotrophy; (3) diazotrophy is compatible with DIN:DIP supply ratios well above Redfield proportions; and (4) communities of diazotrophs competing with ordinary phytoplankton decouple emerging ambient and supply DIN:DIP ratios. Our model predictions appear in line with major observed patterns of diazotrophy in the ocean. The predicted importance of oligotrophy in $\mathrm{P}$ extends the present view of $\mathrm{N}_{2}$ fixation beyond a simple control by excess $\mathrm{P}$ in the surface ocean.
\end{abstract}

KEY WORDS: Nitrogen fixation - Phytoplankton · Optimality · Chain model · Resource allocation · Elemental composition

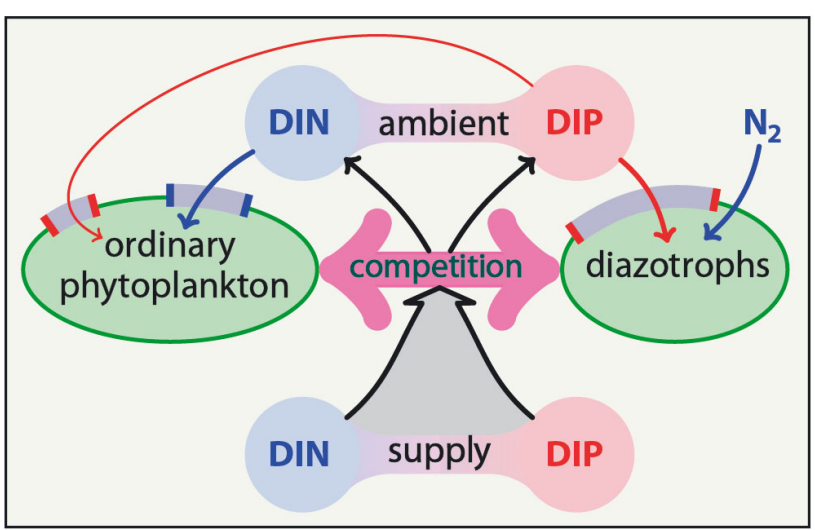

Inorganic nitrogen and phosphorus control the competition between diazotrophs and ordinary phytoplankton, which in turn drives ambient nutrient concentrations; diazotrophs are strong competitors for $\mathrm{P}$, as they can invest more energy into its acquisition.

Image: M. Pahlow

\section{INTRODUCTION}

The biotic cycling of fixed nitrogen $(\mathrm{N})$ in the global ocean modulates the concentration of climate relevant trace gases such as $\mathrm{CO}_{2}$ and $\mathrm{N}_{2} \mathrm{O}$ in the atmosphere (Falkowski 1997, Altabet et al. 2002). Yet the sources and sinks controlling the marine inventory of fixed $\mathrm{N}$ are controversial. This applies to both rates and processes involved (Zehr \& Ward 2002, Langlois et al. 2005, Devol 2008).

This study complements and extends a paradigm that is widely used in marine biogeochemistry: $\mathrm{N}$ fixers or diazotrophs grow more slowly than ordinary phytoplankton against which they compete for bioavailable phosphorus (P) (Falcón et al. 2005, LaRoche \& Breitbarth 2005, Mills \& Arrigo 2010), a limited albeit essential resource in their generally oligotrophic habitats. The ability to fix nitrogen gas 
$\left(\mathrm{N}_{2}\right)$ is an asset in environments depleted of fixed $\mathrm{N}$ because ordinary phytoplankton cannot grow without it. Current implementations of $\mathrm{N}_{2}$ fixation in biogeochemical models have diazotrophs thriving only in those oligotrophic regions in which $\mathrm{N}$ is supplied below the demands of ordinary phytoplankton relative to P supply (Deutsch et al. 2007, Schmittner et al. 2008). The $\mathrm{N}$ deficit is explained by denitrification reducing the deep-ocean dissolved inorganic nitrogen (DIN):dissolved inorganic phosphorus (DIP) ratio below that at which $\mathrm{N}$ and $\mathrm{P}$ are utilised by ordinary phytoplankton in the surface ocean (Lenton \& Klausmeier 2007, Weber \& Deutsch 2012). Additional flavours of this paradigm have been suggested, e.g. limiting effects of micro-nutrients (Mills et al. 2004, Berman-Frank et al. 2007, Sohm et al. 2011) or toxins produced by diazotrophs, which might trigger selective grazing by zooplankton (Hawser et al. 1992).

Several lines of evidence support the paradigm of diazotrophs being favoured in regions which exhibit an inorganic $\mathrm{N}$ deficit relative to $\mathrm{P}$, among them the following. (1) The slow growth of diazotrophs is reasonable given the high energetic cost of reducing $\mathrm{N}_{2}$ to ammonia (Stam et al. 1987) and of avoiding nitrogenase inhibition by oxygen (Großkopf \& LaRoche 2012). (2) The N inventory is likely balanced on multicentennial time scales, which requires a regulating feedback matching $\mathrm{N}$ gains by $\mathrm{N}_{2}$ fixation against $\mathrm{N}$ losses via marine denitrification or anammox (Gruber 2004, Altabet 2007). (3) Such a regulation, e.g. accomplished by diazotrophs competing more successfully if a sink of N lowers the pelagic DIN:DIP ratio below the demands of ordinary phytoplankton, can effectively control the oceanic $\mathrm{N}$ inventory in numerical models (Moore \& Doney 2007, Schmittner et al. 2008). (4) Results from self-assembling coupled global ecosystem circulation models suggest 'that diazotrophs are successful only in the nitrogen-limited and oligotrophic environments' (Monteiro et al. 2011).

However, this view appears difficult to reconcile with the observed distribution of diazotrophs in the world ocean: if the $\mathrm{N}$ deficit was the main driver of $\mathrm{N}_{2}$ fixation, diazotrophy should occur most prominently in regions with high excess $\mathrm{P}$, such as the Eastern Tropical South Pacific (Deutsch et al. 2007). But the observed diazotroph distribution (Monteiro et al. 2010) bears little resemblance to the pattern predicted by Deutsch et al. (2007). For example, diazotrophy is amply documented for the oligotrophic subtropical North Atlantic (Capone et al. 2005, Hynes et al. 2009, Moore et al. 2009), where elevated DIN:DIP ratios in the thermocline are interpreted as the footprint of ongoing $\mathrm{N}_{2}$ fixation in the sun-lit surface layer
(Yoshikawa et al. 2013) and provide the basis of geochemical basin-scale $\mathrm{N}_{2}$ fixation estimates (Hansell et al. 2004, Moore et al. 2009, Kähler et al. 2010). These elevated DIN:DIP ratios cause a high N:P ratio in the upward turbulent macro-nutrient flux to the euphotic zone (Dietze et al. 2004). Indeed, current coupled ecosystem-ocean circulation models seem to require spurious $\mathrm{N}$ sinks (e.g. such as applied in Monteiro et al. 2010, 2011) or a reduced oceanic $N$ inventory (Schmittner et al. 2008) to achieve an inorganic N deficit relative to the Redfield-equivalent of DIP (Redfield 1958) to allow active diazotrophy in this region.

An alternative explanation for diazotrophy in the subtropical North Atlantic, put forward by Mills \& Arrigo (2010), Deutsch \& Weber (2012), and Weber \& Deutsch (2012), is the dominance of phytoplankton groups with higher cellular N:P ratios in this and other oligotrophic regions than in more eutrophic higher-latitude regions. However, this explanation is at odds with laboratory experiments showing that growth conditions exert far greater influence on organism N:P ratio than taxonomy (compare, e.g. Rhee 1978, Healey 1985, Terry et al. 1983, 1985). This, in turn, suggests that, overall, cellular N:P ratios are low under oligotrophic $\mathrm{N}$-limiting conditions and increase only as $\mathrm{N}$ limitation is alleviated.

Published mechanistic models of $\mathrm{N}_{2}$ fixation are also largely founded on the assumptions of high energetic costs and independence of DIN supply. Bissett et al. (1999) treated diazotrophs implicitly, describing $\mathrm{N}_{2}$ fixation as a direct function of light and temperature. Neumann (2000) included P limitation, whereas Hood et al. (2001) considered only light limitation of $\mathrm{N}_{2}$ fixation. Fennel et al. (2002) applied a higher molar N:P ratio (45) for diazotrophs than for other phytoplankton (16). All of these models treated the $\mathrm{N}_{2}$ fixers as obligate diazotrophs. The physiologically more detailed model of $\mathrm{N}_{2}$ fixation by Rabouille et al. (2006) as well as the competition model of Agawin et al. (2007) do not consider $\mathrm{P}$ but allow diazotrophs to utilise both DIN and $\mathrm{N}_{2}$. While field and laboratory studies (Mulholland \& Capone 1999, Mulholland et al. 2001, Holl \& Montoya 2005) show that cyanobacteria can utilise DIN when available, Orcutt et al. (2001) concluded from ${ }^{15} \mathrm{~N}$ incubation experiments that DIN was not an important $\mathrm{N}$ source for $\mathrm{N}_{2}$-fixing cyanobacteria in the subtropical North Atlantic.

In the following, we develop an optimality-based model of $\mathrm{N}_{2}$ fixation derived from generic trade-offs among energy and cellular resource requirements for the acquisition of carbon (C), P, and N. Our optimalitybased model is derived by maximising a goal function (Smith et al. 2011), here assumed to be net balanced 
growth. This approach complements the more conventional method of constructing a mechanistic model on the basis of the underlying biochemical machinery (e.g. Rabouille et al. 2006). It allows a meaningful description of phytoplankton behaviour without explicit reference to many physiological details and enables us to treat diazotrophs in the same modelling framework as ordinary phytoplankton with an additional compartment devoted to $\mathrm{N}_{2}$ fixation. The resulting formulation is validated with existing laboratory observations for ordinary and diazotrophic phytoplankton. We investigate emerging ecological niches by simulating competition experiments between diazotrophs and ordinary phytoplankton under different environmental conditions. We do not account for effects of temperature and iron on $\mathrm{N}_{2}$ fixation (Mills et al. 2004, Houlton et al. 2008). This is a pragmatic decision triggered by the lack of laboratory data available to us, which would be required to validate the interactions between temperature and iron concentration, and nutrient cell quotas and $\mathrm{N}_{2}$ fixation. Thereby we implicitly assume that our model results are valid for warm and iron-replete conditions.

\section{OPTIMAL REGULATION IN A CHAIN MODEL}

\section{Orthogonal hierarchy of cellular functions}

Our optimality-based model of $\mathrm{N}_{2}$ fixation is based on previous optimal growth models (Pahlow 2005, Pahlow \& Oschlies 2009, Wirtz \& Pahlow 2010) and constructed by maximising growth rate in a system characterised by prescribed energetic and resourceallocation trade-offs. $\mathrm{P}, \mathrm{N}$, and $\mathrm{C}$ acquisition are connected via a chain of limitations, where the $\mathrm{P}$ quota limits $\mathrm{N}$ assimilation and the $\mathrm{N}$ quota drives $\mathrm{CO}_{2}$ fixation (Ågren 2004, Pahlow \& Oschlies 2009, Bougaran et al. 2010). The energetic trade-offs are derived from balancing gross $\mathrm{C}$ fixation $\left(V^{\mathrm{C}}\right)$ and respiration losses $(R)$ due to the energy requirements of nutrient acquisition and light harvesting:

$$
\mu=V^{\mathrm{C}}-R
$$

where $\mu$ is relative net growth rate. All symbols are defined in Table 1. The resource-allocation trade-offs are defined in terms of cellular $\mathrm{N}$, via its requirement in structural proteins and all biochemical enzyme activity. Cellular $\mathrm{N}$ is represented here by its biomass-normalised cell quota, or N:C ratio, $Q^{\mathrm{N}}$. Cellular functions are organised into 3 levels, forming an idealised orthogonal hierarchy (Fig. 1). The term orthogonal here means that the optimal allocation at
Table 1. Symbol definitions and units. DIN and DIP: dissolved inorganic nitrogen and phosphorus, respectively; POC, PON and POP: particulate organic carbon, nitrogen and phosphorus, respectively

\begin{tabular}{|c|c|c|}
\hline Symbol & Units & Definition \\
\hline \multicolumn{3}{|c|}{ Parameters } \\
\hline$A_{0}$ & $\mathrm{~m}^{3} \mathrm{~mol}^{-1} \mathrm{~d}^{-1}$ & Potential nutrient affinity \\
\hline$\alpha$ & $\mathrm{m}^{2} \mathrm{E}^{-1} \mathrm{~mol}(\mathrm{~g} \mathrm{chl})^{-1}$ & $\begin{array}{l}\text { Chl-specific light absorp- } \\
\text { tion coefficient }\end{array}$ \\
\hline$\zeta^{\mathrm{chl}}$ & $\mathrm{mol}\left(\mathrm{g} \mathrm{chl}^{-1}\right.$ & $\begin{array}{l}\text { Cost of photosynthesis } \\
\text { coefficient }\end{array}$ \\
\hline$\zeta^{\mathrm{F}}, \zeta^{\mathrm{N}}$ & $\mathrm{mol} \mathrm{mol}^{-1}$ & $\begin{array}{l}\text { Cost of } \mathrm{N}_{2} \text { fixation, DIN } \\
\text { uptake }\end{array}$ \\
\hline$F_{0}^{\mathrm{N}}$ & $\mathrm{mol} \mathrm{mol}^{-1} \mathrm{~d}^{-1}$ & Potential $\mathrm{N}_{2}$ fixation rate \\
\hline$Q_{0}^{\mathrm{N}}, Q_{0}^{\mathrm{P}}$ & $\mathrm{mol} \mathrm{mol}{ }^{-1}$ & Subsistence N, P quota \\
\hline$R_{\mathrm{M}}^{\mathrm{chl}}$ & $\mathrm{d}^{-1}$ & Cost of chl maintenance \\
\hline$V_{0}^{\mathrm{C}}, V_{0}^{\mathrm{N}}, V_{0}^{\mathrm{P}}$ & $\mathrm{mol} \mathrm{mol}{ }^{-1} \mathrm{~d}^{-1}$ & $\begin{array}{l}\text { Potential C, N, P acquisi- } \\
\text { tion rates }\end{array}$ \\
\hline \multicolumn{3}{|c|}{ State variables } \\
\hline$C_{m}$ & $\mathrm{~mol} \mathrm{~m}^{-3}$ & $\begin{array}{l}\text { POC concentration of } \\
\text { organism type } m\end{array}$ \\
\hline$N$ & $\mathrm{~mol} \mathrm{~m}^{-3}$ & DIN concentration \\
\hline$N_{m}$ & $\mathrm{~mol} \mathrm{~m}^{-3}$ & $\begin{array}{l}\text { PON concentration of } \\
\text { organism type } m\end{array}$ \\
\hline$P$ & $\mathrm{~mol} \mathrm{~m}^{-3}$ & DIP concentration \\
\hline$P_{m}$ & $\mathrm{~mol} \mathrm{~m}^{-3}$ & $\begin{array}{l}\text { POP concentration of } \\
\text { organism type } m\end{array}$ \\
\hline \multicolumn{3}{|c|}{ Ordinary variables } \\
\hline$f_{\mathrm{F}}$ & - & $\begin{array}{l}\text { Fraction of } f_{\mathrm{V}} \cdot f_{\mathrm{N}} \cdot Q^{\mathrm{N}} \\
\text { allocated for } \mathrm{N}_{2} \\
\text { fixation }\end{array}$ \\
\hline$f_{\mathrm{N}}$ & - & $\begin{array}{l}\text { Fraction of } f_{\mathrm{V}} \cdot Q^{\mathrm{N}} \text { allo- } \\
\text { cated for } \mathrm{N} \\
\text { assimilation }\end{array}$ \\
\hline$f_{\mathrm{R}}$ & - & $\begin{array}{l}\text { Fraction of } V^{\mathrm{C}} \text { released } \\
\text { as DOC }\end{array}$ \\
\hline$f_{\mathrm{V}}$ & - & $\begin{array}{l}\text { Fraction of } Q^{\mathrm{N}} \text { allocated } \\
\text { for nutrient acquisition }\end{array}$ \\
\hline$F^{\mathrm{N}}$ & $\mathrm{mol} \mathrm{mol}^{-1} \mathrm{~d}^{-1}$ & $\mathrm{~N}_{2}$ fixation rate \\
\hline$\hat{F}_{*}^{N}$ & $\mathrm{~mol} \mathrm{~mol}^{-1} \mathrm{~d}^{-1}$ & 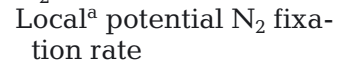 \\
\hline$I$ & $E \mathrm{~m}^{-2} \mathrm{~d}^{-1}$ & Irradiance \\
\hline$L_{\mathrm{d}}$ & - & $\begin{array}{l}\text { Day length as a fraction } \\
\text { of } 24 \mathrm{~h}\end{array}$ \\
\hline$\mu$ & $\mathrm{d}^{-1}$ & Net growth rate \\
\hline$N_{\text {so }}$ & $\mathrm{mol} \mathrm{m}^{-3}$ & $\begin{array}{l}\text { Switch-over DIN concen- } \\
\text { tration }\end{array}$ \\
\hline$Q^{\mathrm{N}}, Q^{\mathrm{P}}$ & $\mathrm{mol} \mathrm{mol}^{-1}$ & $\mathrm{~N}: \mathrm{C}, \mathrm{P}: \mathrm{C}$ ratio $(\mathrm{N}, \mathrm{P}$ quota \\
\hline$Q_{\mathrm{s}}^{\mathrm{N}}$ & $\mathrm{mol} \mathrm{mol}^{-1}$ & $\begin{array}{l}\text { Partial N quota bound in } \\
\text { structural protein }\end{array}$ \\
\hline$R$ & $d^{-1}$ & Respiration \\
\hline$R^{\mathrm{chl}}$ & $d^{-1}$ & Cost of photosynthesis \\
\hline$S^{\mathrm{I}}$ & - & Degree of light saturation \\
\hline$\theta, \hat{\theta}$ & $(\mathrm{g}$ chl $) \mathrm{mol}^{-1}$ & $\begin{array}{l}\text { Whole-cell, chloroplast } \\
\text { chl:C ratio }\end{array}$ \\
\hline$V^{\mathrm{C}}, V^{\mathrm{N}}, V^{\mathrm{P}}$ & $\mathrm{mol} \mathrm{mol}^{-1} \mathrm{~d}^{-1}$ & $\begin{array}{l}\text { Whole-cell } \mathrm{C}, \mathrm{N}, \mathrm{P} \text { acqui- } \\
\text { sition rates }\end{array}$ \\
\hline$V_{\max }^{\mathrm{N}}, V_{\max }^{\mathrm{P}}$ & $\mathrm{mol} \mathrm{mol}^{-1} \mathrm{~d}^{-1}$ & $\begin{array}{l}\text { Maximum N, } \mathrm{P} \text { assimila- } \\
\text { tion rates }\end{array}$ \\
\hline$V_{\mathrm{T}}^{\mathrm{N}}$ & $\mathrm{mol} \mathrm{mol}^{-1} \mathrm{~d}^{-1}$ & Total $\mathrm{N}$ acquisition rate \\
\hline$\hat{V}^{\mathrm{N}}, \hat{V}^{\mathrm{P}}$ & $\mathrm{mol} \mathrm{mol}^{-1} \mathrm{~d}^{-1}$ & Local $^{\mathrm{a}}$ N, P uptake rates \\
\hline$\hat{V}_{*}^{\mathrm{N}}, \hat{V}_{*}^{\mathrm{P}}$ & $\mathrm{mol} \mathrm{mol}{ }^{-1} \mathrm{~d}^{-1}$ & $\begin{array}{l}\text { Local }^{\mathrm{a}} \text { potential N, } \mathrm{P} \text { assi- } \\
\text { milation rates }\end{array}$ \\
\hline$\hat{V}_{\mathrm{T}}^{\mathrm{N}}$ & $\mathrm{mol} \mathrm{mol}{ }^{-1} \mathrm{~d}^{-1}$ & $\begin{array}{l}\text { Local }^{\mathrm{a}} \text { total } \mathrm{N} \text { acquisition } \\
\text { rate }\end{array}$ \\
\hline
\end{tabular}




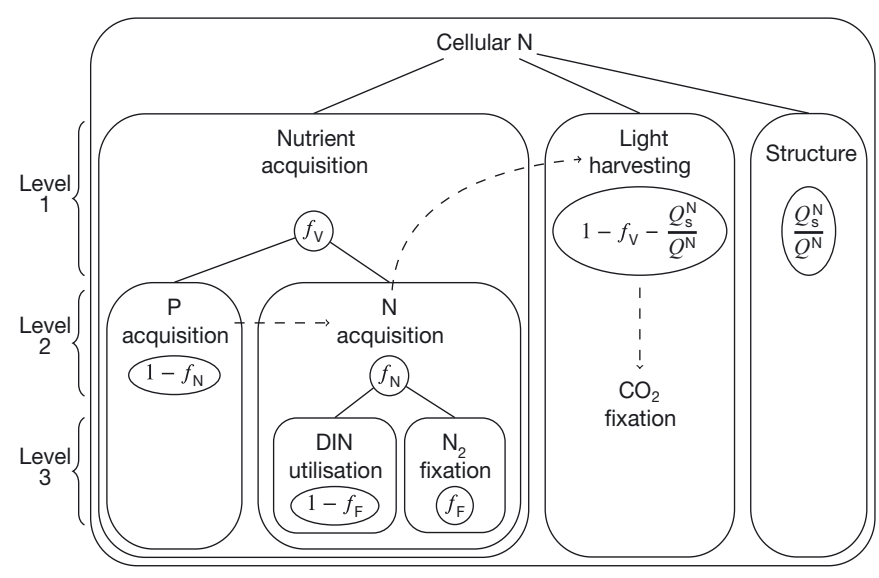

Fig. 1. Idealised orthogonal hierarchy of $\mathrm{N}$ allocation among cellular functions. Level 1 encompasses the whole cell and divides cellular $\mathrm{N}$ into 3 fractions, devoted to nutrient acquisition $\left(f_{\mathrm{V}}\right)$, structural protein $\left(Q_{\mathrm{s}}^{\mathrm{N}} / Q^{\mathrm{N}}\right)$, and light harvesting $\left(1-f_{\mathrm{V}}-Q_{\mathrm{s}}^{\mathrm{N}} / Q^{\mathrm{N}}\right)$. Level 2 partitions nutrient acquisition into $\mathrm{P}$ - and $\mathrm{N}$-acquisition compartments, described by the allocation factor $f_{\mathrm{N}}$. Level 3 partitions the $\mathrm{N}$ acquisition branch into compartments responsible for dissolved inorganic nitrogen (DIN) uptake and $\mathrm{N}_{2}$ fixation via allocation factor $f_{\mathrm{F}}$. Dashed arrows indicate the chain of interactions among $P$, $\mathrm{N}$, and $\mathrm{C}$ acquisition (see Fig. 2 for details)

each level is independent of the allocation at other levels, which is a requirement to obtain an algebraically tractable system. While this requirement forces us to neglect certain (minor) feedbacks, e.g. direct effects of $\mathrm{P}$ on light harvesting, it does allow consideration of all major effects of $\mathrm{N}$ and $\mathrm{P}$ in a phytoplankton cell. Cellular functions are optimised for balanced growth at each level individually. The orthogonal construction of the functional hierarchy thereby ensures that this results in the maximal balanced net growth rate of the whole cell. The balanced-growth assumption involved in deriving the optimal regulation likely limits the suitability of the model to time scales of about a day or longer. This should not be problematic, however, for the intended use of the model in large-scale biogeochemical models.

\section{Level 1: Nutrient acquisition and light harvesting}

Level 1 is the highest level and encompasses the whole cell, and thus corresponds conceptually to the allocation schemes developed by Bruggeman \& Kooijman (2007) and Wirtz \& Pahlow (2010). At Level 1, cellular $\mathrm{N}$ is subdivided into 3 parts: (1) a constant amount $\left(Q_{\mathrm{s}}^{\mathrm{N}}\right)$ bound in structural protein, (2) a variable amount allocated to nutrient acquisition, and (3) the remaining cellular $\mathrm{N}$ available for light harvesting and $\mathrm{C}$ fixation. With the help of the allocation factor $f_{\mathrm{V}}$, defined as the fraction of cellular $\mathrm{N}$ devoted to nutrient acquisition, we thus define 3 fractions of cellular $\mathrm{N}$ : the fraction $Q_{\mathrm{s}}^{\mathrm{N}} / Q^{\mathrm{N}}$ for structural protein, the fraction $f_{\mathrm{V}}$ for the nutrient-acquisition compartment, and the fraction $1-f_{\mathrm{V}}-Q_{\mathrm{s}}^{\mathrm{N}} / Q^{\mathrm{N}}$ for the lightharvesting compartment. For simplicity, we refer to the light-harvesting compartment as the chloroplast, even though cyanobacteria do not possess chloroplasts. The model chloroplast thus contains the pigments but also all enzymes involved in $\mathrm{C}$ fixation. Assuming equal $\mathrm{N}: \mathrm{C}$ ratios in the chloroplast and protoplast (intended here to refer to everything outside the chloroplast, see Pahlow \& Oschlies 2009, 2013), C fixation $\left(V^{\mathrm{C}}\right), \mathrm{N}$ assimilation $\left(V^{\mathrm{N}}\right)$, and respiration $(R)$ can be written in terms of $Q^{\mathrm{N}}$ and the chlorophyll (chl):C ratio of the chloroplast $(\hat{\theta})$ as:

$$
\begin{gathered}
V^{\mathrm{C}}=V_{0}^{\mathrm{C}}\left(1-\frac{Q_{\mathrm{S}}^{\mathrm{N}}}{Q^{\mathrm{N}}}-f_{\mathrm{V}}\right) S^{\mathrm{I}}, S^{\mathrm{I}}=1-\exp \left(-\frac{\alpha \hat{\theta} I}{V_{0}^{\mathrm{C}}}\right) \\
V^{\mathrm{N}}=f_{\mathrm{V}} \hat{V}^{\mathrm{N}} \\
R=R^{\mathrm{chl}}+\zeta^{\mathrm{N}} V^{\mathrm{N}}
\end{gathered}
$$

where $V_{0}^{\mathrm{C}}$ is the potential $\mathrm{CO}_{2}$ fixation rate, $S^{\mathrm{I}}$ is the light saturation of the chloroplast, $\alpha$ is the chl-specific light absorption coefficient, $I$ is the irradiance, $\hat{V}^{\mathrm{N}}$ is the local rate of $\mathrm{N}$ uptake with respect to the nutrient-acquisition compartment, $R^{\text {chl }}$ is the cost of photosynthesis, and $\zeta^{\mathrm{N}} V^{\mathrm{N}}$ is the cost of $\mathrm{N}$ assimilation. The assumption of equal $\mathrm{N}: \mathrm{C}$ ratios in the protoplast and chloroplast implies that $\mathrm{N}$ and $\mathrm{C}$ resources are allocated in parallel across the entire cell. Within the light-harvesting apparatus in the chloroplast, chlorophyll synthesis is optimised, balancing $\mathrm{C}$ fixation and the respiratory energy requirement for the photosynthetic apparatus itself (Appendix 1).

Growth rate is maximised at this level by finding the optimal allocation factor for nutrient acquisition $\left(f_{\mathrm{V}}^{\mathrm{o}}\right)$, which is defined as the one maximising net balanced growth rate $(\bar{\mu})$ :

$$
\frac{\mathrm{d} \bar{\mu}}{\mathrm{d} f_{\mathrm{V}}}=0 \Leftrightarrow f_{\mathrm{V}}^{\mathrm{o}}=\frac{Q_{\mathrm{s}}^{\mathrm{N}}}{Q^{\mathrm{N}}}-\zeta^{\mathrm{N}}\left(Q^{\mathrm{N}}-2 Q_{\mathrm{s}}^{\mathrm{N}}\right)
$$

where the overbar denotes the balanced-growth assumption (see Pahlow \& Oschlies 2013 for derivation).

\section{Level 2: Nitrogen and phosphorus acquisition}

Level 2 allocates the cellular $\mathrm{N}$ devoted to nutrient acquisition into 2 compartments responsible for $\mathrm{N}$ and $\mathrm{P}$-acquisition via the allocation factor $f_{\mathrm{N}} \mathrm{N}$ and $\mathrm{P}$ 
uptake and assimilation are expressed in terms of local rates $\left(\hat{V}^{\mathrm{N}}, \hat{V}^{\mathrm{P}}\right)$, i.e. with respect to the nutrientacquisition compartment, which contains the fraction $f_{\mathrm{V}}$ of the available cellular $\mathrm{N}$ resources. $f_{\mathrm{N}}$ is defined as that fraction of $\mathrm{N}$ within the nutrient-acquisition compartment that is devoted to $\mathrm{N}$ uptake and assimilation. Thus, the fraction of cellular $\mathrm{N}$ allocated to $\mathrm{N}$ acquisition is given by the product $f_{\mathrm{V}} f_{\mathrm{N}}$ and the fraction allocated to $\mathrm{P}$ acquisition is $f_{\mathrm{V}}\left(1-f_{\mathrm{N}}\right)$. As in previous optimal-growth models (Pahlow 2005, Pahlow \& Oschlies 2009), nutrient uptake is formulated as optimal uptake kinetics (Smith \& Yamanaka 2007):

$$
\begin{gathered}
V^{\mathrm{N}}=f_{\mathrm{V}} \hat{V}^{\mathrm{N}}=f_{\mathrm{V}} f_{\mathrm{N}} \hat{V}_{*}^{\mathrm{N}} \quad V^{\mathrm{P}}=f_{\mathrm{V}} \hat{V}^{\mathrm{P}}=f_{\mathrm{V}}\left(1-f_{\mathrm{N}}\right) \hat{V}_{*}^{\mathrm{P}} \\
\hat{V}_{*}^{\mathrm{N}}=\left(\sqrt{\frac{1}{V_{\max }^{\mathrm{N}}}}+\sqrt{\frac{1}{A_{0} N}}\right)^{-2} \quad \hat{V}^{\mathrm{P}}=\left(\sqrt{\frac{1}{V_{\max }^{\mathrm{P}}}}+\sqrt{\frac{1}{A_{0} P}}\right)^{-2}
\end{gathered}
$$

where $\hat{V}_{*}^{\mathrm{N}}$ and $\hat{V}_{*}^{\mathrm{P}}$ are the local potential rates of $\mathrm{N}$ and $\mathrm{P}$ assimilation, respectively. $A_{0}$ is the potential nutrient affinity, $V_{\max }^{\mathrm{N}}$ and $V_{\max }^{\mathrm{P}}=V_{0}^{\mathrm{P}}$ are the maximum rates of $\mathrm{N}$ and $\mathrm{P}$ uptake, respectively. $N$ and $P$ are ambient DIN and DIP concentrations, respectively. For simplicity, DIN represents both nitrate and ammonium here. We do not explicitly account for leakage, so Eq. (6) describes net $\mathrm{N}$ and $\mathrm{P}$ uptake. For simplicity, Eq. (7) does not consider diffusion effects (also, Armstrong 2008 found no improvement in model behaviour when including diffusion).

We describe the physiological interaction between $\mathrm{N}$ and $\mathrm{P}$ cell quotas by a chain of limitations (Fig. 2). At the base of this limitation chain is $\mathrm{P}$, which is most important for ribosomes, where biosynthesis combines amino acids into proteins (Sterner \& Elser 2002). Thus, cellular P controls $\mathrm{N}$ assimilation. $\mathrm{N}$, in turn, is essential for enzymes performing most other cellular functions, which, eventually, limit growth. The effect of $\mathrm{P}$ on $\mathrm{N}$ assimilation is treated as a P quota dependence of the maximum $\mathrm{N}$ assimilation rate of the nutrient-acquisition compartment $\left(V_{\max }^{\mathrm{N}}\right)$ :

$$
V_{\max }^{\mathrm{N}}=V_{0}^{\mathrm{N}}\left(1-\frac{Q_{0}^{\mathrm{P}}}{Q^{\mathrm{P}}}\right)
$$

where $V_{0}^{\mathrm{N}}$ is potential $\mathrm{N}$ uptake rate under P-replete conditions and $Q_{0}^{\mathrm{P}}$ is the $\mathrm{P}$ subsistence quota, assumed here to represent phospholipids and nucleic acids outside the ribosomes (Sterner \& Elser 2002). The shape of Eq. (8) was chosen because it allows us to formulate the model without explicitly specifying the upper limit of $Q^{\mathrm{P}}$, which would not be the case for a linear dependence of $V_{\max }^{\mathrm{N}}$ on $Q^{\mathrm{P}}$. In this respect, Eq. (8) is thus the simplest choice, because it does not require any additional parameters to constrain the range of $Q^{\mathrm{P}}$.

The optimal allocation factor for $\mathrm{N}$ acquisition $\left(f_{\mathrm{N}}^{\mathrm{o}}\right)$ is found by maximising the net balanced growth rate with respect to $f_{\mathrm{N}}$ :

$$
\begin{gathered}
\frac{\mathrm{d} \bar{\mu}}{\mathrm{d} f_{\mathrm{N}}} \stackrel{!}{=} 0 \Leftrightarrow \frac{\mathrm{d} \hat{V}^{\mathrm{N}}}{\mathrm{d} f_{\mathrm{N}}}=0 \\
\Leftrightarrow f_{\mathrm{N}}^{\mathrm{o}}=\frac{1}{1+\sqrt{\frac{Q^{\mathrm{P}} \mathscr{B}}{Q^{\mathrm{N}} \hat{V}_{*}^{\mathrm{P}}}}}, \quad \mathscr{B}=\frac{\hat{V}_{*}^{\mathrm{N}}}{\left(\frac{Q^{\mathrm{P}}}{Q_{0}^{\mathrm{P}}}-1\right) \sqrt{\frac{V_{0}^{\mathrm{N}}}{\hat{V}_{*}^{\mathrm{N}}}\left(1-\frac{Q_{0}^{\mathrm{P}}}{Q^{\mathrm{P}}}\right)}}
\end{gathered}
$$

where we introduce $\mathscr{B}$ for notational convenience. We found the expression for $f_{\mathrm{N}}^{o}$ in Eq. (10) by accident, during an attempt to find an approximation for $f_{\mathrm{N}^{\prime}}^{o}$ and could only confirm it numerically. Graphical analysis shows that, if the system is not in steady state, Eq. (10) yields an approximation for $f_{\mathrm{N}}^{\circ}$ that converges towards the steady-state solution. Eq. (9) ensures that Levels 1 and 2 are orthogonal, i.e. $f_{\mathrm{N}}$ can be optimised independently of $f_{\mathrm{V}}$. As $\bar{\mu}$ is a monotonic function of $Q^{\mathrm{N}}$ (Pahlow \& Oschlies 2013), $f_{\mathrm{N}}=f_{\mathrm{N}}^{\circ}$

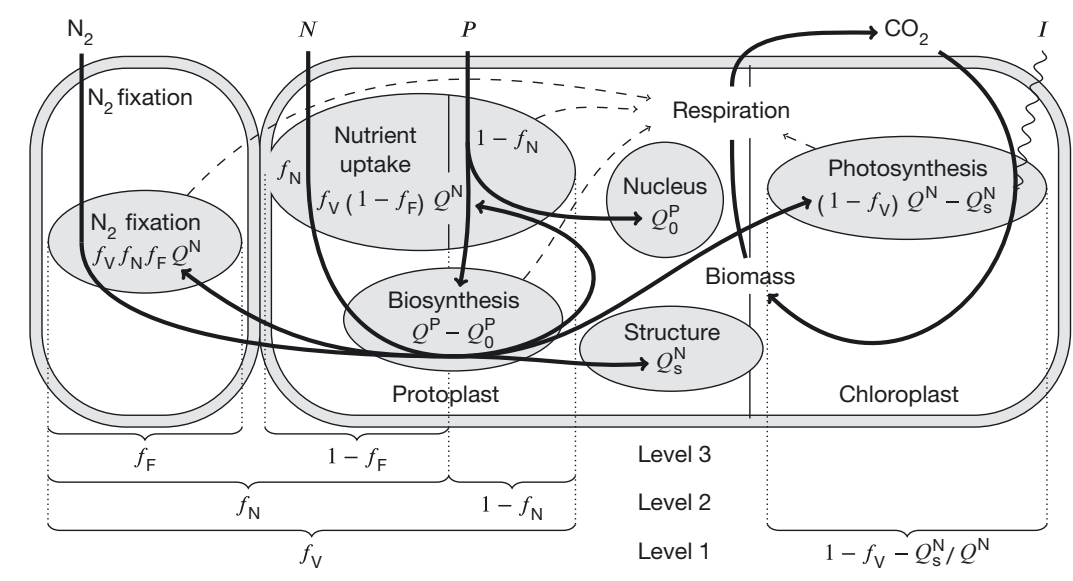

Fig. 2. Allocation schema and roles of cellular $\mathrm{N}$ and $\mathrm{P}$ (represented by $Q^{\mathrm{N}}$ and $Q^{\mathrm{P}}$ ) in our model compartments (representing cell functions). Cellular $\mathrm{N}$ is sequentially distributed, across 3 levels, among the demands for structural material, photosynthesis, nutrient uptake, and $\mathrm{N}_{2}$ fixation. $\mathrm{N}$ allocation is described by 3 allocation factors: $f_{\mathrm{V}}$, between photosynthesis and nutrient acquisition (Level 1); $f_{\mathrm{N}}$, between $\mathrm{N}$ and $\mathrm{P}$ uptake (Level 2); and $f_{\mathrm{F}}$, between uptake of dissolved inorganic $\mathrm{N}$ and $\mathrm{N}_{2}$ fixation (Level 3). See Fig. 1 for details of the optimal allocation scheme. Cellular $\mathrm{P}$ is divided between the nucleus $\left(Q_{0}^{\mathrm{P}}\right)$ and the ribosomes $\left(Q^{\mathrm{P}}-Q_{0}^{\mathrm{P}}\right)$, which are responsible for biosynthesis of newly acquired cellular $\mathrm{N}$ into protein. Thick arrows indicate material flows of $\mathrm{C}, \mathrm{N}$, and P. Dashed arrows indicate energy requirements of individual processes. Note that the separation of $\mathrm{N}_{2}$ fixation from the other functional compartments may be either spatial or temporal. $I$ : irradiance 
maximises overall net balanced growth rate. Eq. (10) is an implicit equation for balanced growth, since it involves $Q^{\mathrm{P}}$, but can be applied directly in forward simulations, where $Q^{\mathrm{P}}$ is known.

\section{Level 3: DIN uptake and nitrogen fixation}

Facultative diazotrophy is incorporated into the chain model via a new compartment dedicated to $\mathrm{N}_{2}$ fixation, which is separate from the photosynthetic and nutrient-acquisition compartments (Figs. 1 \& 2). This is achieved in a mathematically convenient way by splitting the $\mathrm{N}$-acquisition compartment into a fraction responsible for $\mathrm{N}_{2}$ fixation $\left(f_{\mathrm{F}}\right)$ and a fraction responsible for DIN uptake $\left(1-f_{\mathrm{F}}\right)$. This implies that $\mathrm{N}_{2}$ fixation is carried out at the cost of the DIN utilisation capacity. Thus, $f_{\mathrm{F}}$ is defined relative to the $\mathrm{N}$ assimilation compartment, i.e. relative to the fraction $f_{\mathrm{V}} f_{\mathrm{N}}$ of cellular $\mathrm{N}$ (Fig. 1). Total $\mathrm{N}$ assimilation is then:

$$
\begin{aligned}
& V_{\mathrm{T}}^{\mathrm{N}}=V^{\mathrm{N}}+F^{\mathrm{N}}=f_{\mathrm{V}} \hat{V}_{\mathrm{T}}^{\mathrm{N}}=f_{\mathrm{V}} f_{\mathrm{N}}\left[\left(1-f_{\mathrm{F}}\right) \hat{V}_{*}^{\mathrm{N}}+f_{\mathrm{F}} \hat{F}_{*}^{\mathrm{N}}\right], \\
& \hat{F}_{*}^{\mathrm{N}}=\left(1-\frac{Q_{0}^{\mathrm{P}}}{Q^{\mathrm{P}}}\right) F_{0}^{\mathrm{N}}
\end{aligned}
$$

where $F_{\mathrm{N}}$ and $\hat{F}_{*}^{\mathrm{N}}$ are defined as actual and local (relative to the nutrient-acquisition compartment) potential $\mathrm{N}_{2}$ fixation, respectively. As for Eq. (6), Eq. (11) describes net $\mathrm{N}$ acquisition via $\mathrm{N}_{2}$ fixation, which assumes that all ammonium leaking out of the $\mathrm{N}_{2}$ fixing compartment is utilised by the diazotroph (Mulholland \& Bernhardt 2005). $F_{\mathrm{N}}^{\mathrm{o}}$ is the potential $\mathrm{N}_{2}$ fixation rate of the $\mathrm{N}_{2}$ fixation compartment. Exclusive $\mathrm{N}_{2}$ fixation will thus occur for $N=0 \Leftrightarrow \hat{V}_{*}^{\mathrm{N}}$ $=0$ ) or $f_{\mathrm{F}}=1$. The energy requirement of $\mathrm{N}_{2}$ fixation is expressed as respiration costs $\zeta^{\mathrm{F}} F^{\mathrm{N}}$ :

$$
\begin{aligned}
& \mu=V_{0}^{\mathrm{C}}\left(1-f_{V}-\frac{Q_{0}^{\mathrm{N}}}{Q^{\mathrm{N}}}\right) S^{\mathrm{I}}-R^{\mathrm{chl}}-f_{V} \zeta_{\text {eff }}^{\mathrm{N}} \hat{V}_{T}^{\mathrm{N}}, \\
& \zeta_{\mathrm{eff}}^{\mathrm{N}}=\frac{\zeta^{\mathrm{N}}\left(1-f_{\mathrm{F}}\right) \hat{V}_{*}^{\mathrm{N}}+\zeta^{\mathrm{F}} f_{\mathrm{F}} \hat{F}_{*}^{\mathrm{N}}}{\left(1-f_{\mathrm{F}}\right) \hat{V}^{\mathrm{N}}+f_{\mathrm{F}} \hat{F}_{*}^{\mathrm{N}}}
\end{aligned}
$$

where $\zeta^{\mathrm{F}}$ is the extra respiration cost of $\mathrm{N}_{2}$ fixation and $\zeta_{\text {eff }}^{F}$ is the effective cost of $\mathrm{N}$ acquisition. The optimal allocation $f_{\mathrm{N}}^{\circ}$ allowing for $\mathrm{N}_{2}$ fixation is found analogously to Eq. (10) by maximising $\hat{V}_{\mathrm{T}}^{\mathrm{N}}$ with respect to $f_{\mathrm{N}}$ :

$$
f_{\mathrm{N}}^{\mathrm{o}}=\frac{1}{1+\sqrt{\frac{\left(1-f_{\mathrm{F}}\right) Q^{\mathrm{P}} \mathscr{B}+f_{\mathrm{F}} Q_{0}^{\mathrm{P}} F_{0}^{\mathrm{N}}}{Q^{\mathrm{N}} \hat{V}_{*}^{\mathrm{P}}}}}
$$

which is identical to Eq. (10) for $f_{\mathrm{F}}=0$. In the case of pure $\mathrm{N}_{2}$ fixation, i.e. for $N=0$ or $f_{\mathrm{F}}=1, f_{\mathrm{N}}^{\mathrm{o}}$ can be derived analytically by eliminating $Q^{\mathrm{P}}$ in Eq. (11) and solving the derivative of $\hat{V}_{\mathrm{T}}^{\mathrm{N}}$ with respect to $f_{\mathrm{N}}$. As is the case with Eq. (10), Eq. (13) could also only be verified numerically.

$\zeta_{\text {eff }}^{\mathrm{N}}$ in Eq. (12) depends on $f_{\mathrm{N}}$ (because $\hat{V}_{*}^{\mathrm{N}}$ and $\hat{F}_{*}^{\mathrm{N}}$ depend on $Q^{\mathrm{P}}$ and $Q^{\mathrm{P}}$ depends on $f_{\mathrm{N}}$ ), which appears to break the orthogonality of Levels 1 and 2, as this introduces a mutual dependency between $f_{\mathrm{N}}^{\mathrm{o}}$ and $f_{\mathrm{V}}^{\mathrm{o}}$. However, net balanced growth rate $(\bar{\mu})$ never displays a maximum when plotted as a function of $f_{\mathrm{F}}$, i.e. $\bar{\mu}$ is essentially monotonic (a slight minimum can occur when $\left.\left.\bar{\mu}\right|_{f_{\mathrm{F}}=0} \approx \bar{\mu}\right|_{f_{\mathrm{F}}=1}$ ) in $f_{\mathrm{F}}$ for $0 \leq f_{\mathrm{F}} \leq 1$ (see Fig. 6A for an example). Thus, the optimal allocation factor for $\mathrm{N}_{2}$ fixation $\left(f_{\mathrm{F}}^{\circ}\right)$ is either 0 or 1 . This means that $f_{\mathrm{F}}^{\circ}$ is effectively switching between $\mathrm{N}_{2}$ fixation and DIN utilisation: at low DIN concentrations, the diazotroph should fix $\mathrm{N}_{2}$ and not utilise any DIN ( $f_{\mathrm{F}}=$ 1), and at high ambient DIN concentrations, DIN should be utilised without the diazotroph fixing any $\mathrm{N}_{2}\left(f_{\mathrm{F}}=0\right)$. Combining DIN utilisation and $\mathrm{N}_{2}$ fixation is never optimal, hence we need not consider the exact form of Eq. (13) for $0<f_{\mathrm{F}}<1$ for implementing the optimal $\mathrm{N}_{2}$ fixation model. Thus, the inter-dependence between $f_{\mathrm{N}}^{\circ}$ and $f_{\mathrm{V}}^{\circ}$ can be safely ignored and Levels 1 and 2 are indeed orthogonal.

\section{VALIDATION}

The behaviour of the allocation factors $f_{\mathrm{V}}$ and $f_{\mathrm{N}}$ of the optimal chain model defined in Eqs. (1) to (10)
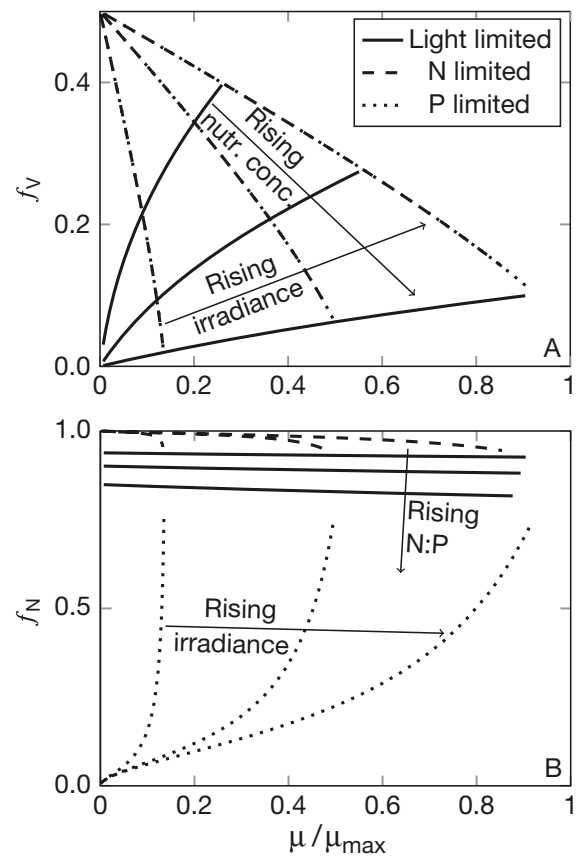

Fig. 3. Behaviour of the allocation factors (A) $f_{\mathrm{V}}$ and (B) $f_{\mathrm{N}}$ in relation to normalised growth rate $\mu$ (relative to its maximum, $\left.\mu_{\max }\right)$ under light-, $\mathrm{N}-$, and P-limiting conditions 
Table 2. Parameter estimates for Trichodesmium (Figs. 5 \& 6), the non-diazotrophic cyanobacterium Synechococcus linearis, the diatoms Thalassiosira fluviatilis and Phaeodactylum tricornutum, and the green alga Scenedesmus sp. (Fig. 4). Units are defined in Table 1

\begin{tabular}{|lccccccccccc|}
\hline Species & $A_{0}$ & $\alpha$ & $Q_{0}^{\mathrm{N}}$ & $Q_{0}^{\mathrm{P}}$ & $V_{0}^{\mathrm{C}}, V_{0}^{\mathrm{N}}, V_{0}^{\mathrm{P}}$, & $R_{\mathrm{M}}^{\mathrm{chl}}$ & $\zeta^{\mathrm{chl}}$ & $\zeta^{\mathrm{N}}$ & $F_{0}^{\mathrm{N}}$ & $\zeta^{\mathrm{F}}$ \\
\hline Trichodesmium sp. & 60 & 3.7 & 0.13 & 0.0027 & 5 & 0.1 & 0.6 & 0.7 & 1.3 & 2 \\
T. fluviatilis & 70 & 1.6 & 0.046 & 0.0008 & 5 & 0.1 & 0.55 & 0.75 & - & - \\
S. linearis & 90 & 1.4 & 0.086 & 0.0012 & 5 & 0.1 & 0.4 & 0.6 & - & - \\
P. tricornutum & 150 & 0.9 & 0.056 & 0.002 & 5 & 0.1 & 0.35 & 1.0 & - & - \\
Scenedesmus sp. & 1000 & 0.5 & 0.05 & 0.0012 & 5 & 0.1 & 0.4 & 0.6 & - & - \\
\hline
\end{tabular}

single maximum-rate parameter. Thus, the number of tuning parameters remains the same as in the conceptually inferior model of Pahlow \& Oschlies (2009).

Note that the respiration cost of $\mathrm{N}$ assimilation $\left(\zeta^{\mathrm{N}}\right)$ is only a minor contribution to total respiration here (Pahlow \& Oschlies 2013), most is illustrated in Fig. 3. The model was validated for ordinary phytoplankton, i.e. without $\mathrm{N}_{2}$ fixation $\left(f_{\mathrm{F}}=0\right)$, against the identical data sets previously used and described by Pahlow \& Oschlies (2009). The model parameters were hand-tuned until a good fit (gauged visually) to the data was obtained (lower 4 rows of Table 2, Fig. 4). An interesting result of the tuning exercise was that a good agreement between the data and the model could be achieved by assuming identical potential acquisition rates of $\mathrm{C}, \mathrm{N}$, and $\mathrm{P}$, i.e. $V_{0}^{\mathrm{C}}=$ $V_{0}^{\mathrm{N}}=V_{0}^{\mathrm{P}}$, implying that they can be replaced by a of which is associated with maintaining the photosynthetic apparatus in the present model (Eqs. 4 \& A1). Therefore, our estimate for $\zeta^{\mathrm{N}}$ is much smaller than in Pahlow \& Oschlies (2009) and other phytoplankton growth models. The treatment of maintenance respiration according to the cellular chl:C ratio (Eq. A1) is a major conceptual difference to previous phytoplankton growth models. Our formulation can reconcile the apparent absence of maintenance respiration under nutrient limitation (e.g. Geider et al. 1998 have set maintenance respiration to 0 for all

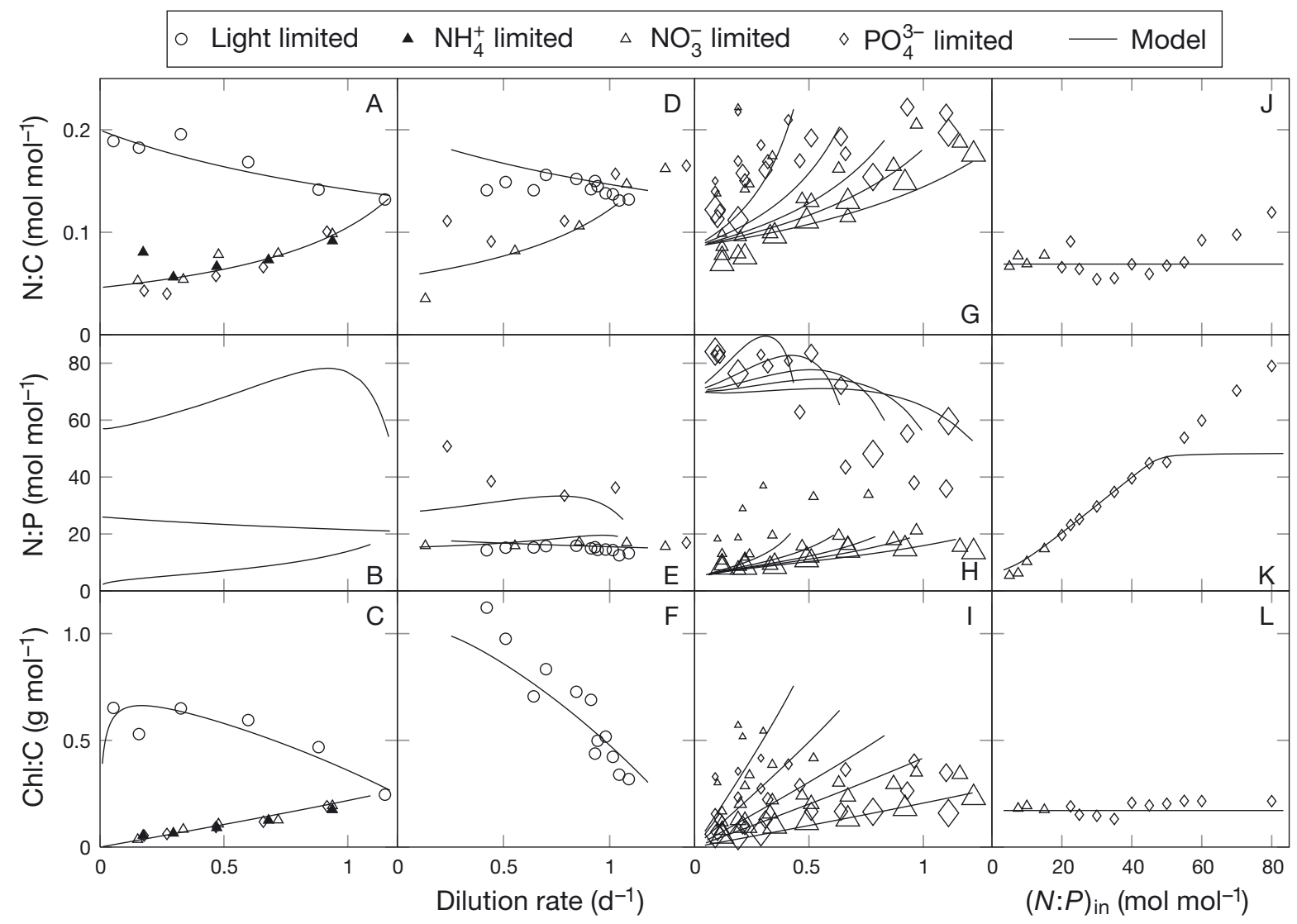

Fig. 4. Model validation for ordinary (non- $\mathrm{N}_{2}$-fixing) phytoplankton. Data (symbols) and model predictions (lines) for (A-C) Thalassiosira fluviatilis from Laws \& Bannister (1980), (D-F) Phaeodactylum tricornutum from Terry et al. (1985), (G-I) Synechococcus linearis for 5 light levels from Healey (1985), and (J-L) Scenedesmus sp. for constant dilution rate from Rhee (1974). Light intensity increases with symbol size and lines from left to right in G-I. Model parameters are listed in Table 2 


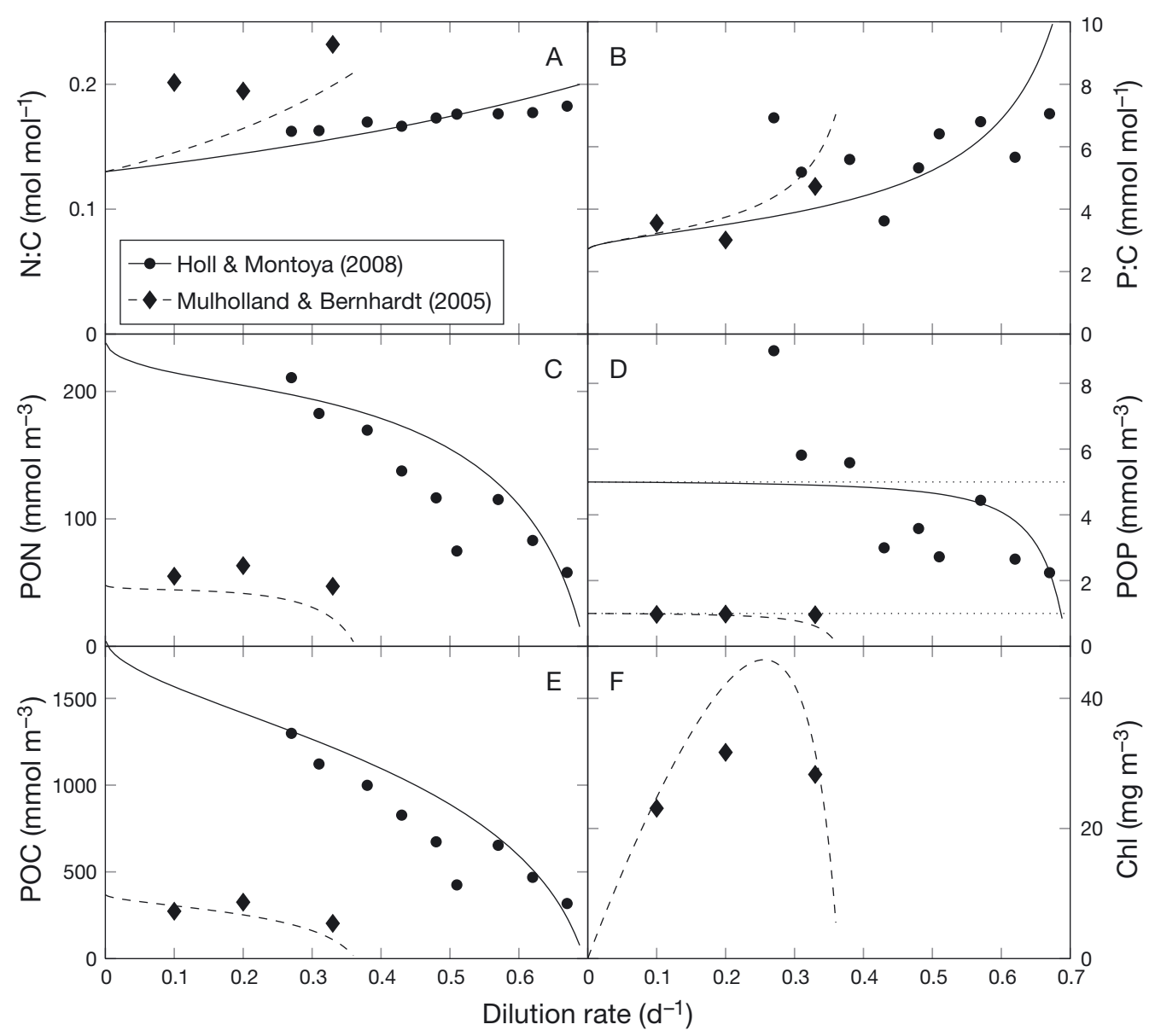

Fig. 5. Fit of optimal $\mathrm{N}_{2}$ fixation to observations from Mulholland \& Bernhardt (2005) and Holl \& Montoya (2008). The thin dotted lines in (D) indicate P concentrations in the supply. Particulate organic phosphorus (POP) was estimated from the difference between the dissolved inorganic P (DIP) concentrations in the inflow and in the culture chamber for the study of Mulholland \& Bernhardt (2005). Parameter settings for Trichodesmium sp. are from Table 2. POC and PON: particulate organic carbon and nitrogen, respectively

steady-state simulations of nutrient-limited cultures) with observations of a minimum light requirement for growth (Quigg \& Beardall 2003). The main effect on the model behaviour is that a threshold irradiance is introduced (Eq. A5), below which no chlorophyll is produced, causing a downregulation of the chl:C ratio at very low irradiance (Fig. 4 C). This might help to reduce the problem of too-intense deep chlorophyll maxima relative to surface concentrations reported by Pahlow et al. (2008).

A model validation for the case of pure $\mathrm{N}_{2}$ fixation $\left(f_{\mathrm{F}}=1\right)$ is presented in Fig. 5, where model predictions are compared with observations from 2 independent incubation experiments with Trichodesmium erythraeum. As both data sets used in Fig. 5 were obtained with the same species, only a single parameter set was used for Trichodesmium sp. (Table 2). Simulations and experiments differed only in DIP concentration and light intensity. To our knowledge, Fig. 5 shows all available observations relating chl:C, N:C, and P:C to steady-state growth rate for diazotrophic phytoplankton.

Table 2 indicates a much higher chlorophyll-specific light absorption coefficient $(\alpha)$ for Trichodesmium sp. compared with the other species. This is apparently consistent with measurements by de Tezanos Pinto \& Litchman (2010), who reported a high $\alpha$ of similar magnitude for the diazotroph Anabaena flos-aquae. Further, the light absorption coefficient $\alpha$ appears to vary inversely with potential nutrient affinity $A_{0}$ (Table 2), which indicates that phytoplankton species may be adapted to either low light or low nutrient conditions, but not to both. As it is unclear what could cause such an inverse relationship, it may also just be a coincidence. Nevertheless, such a relationship might prove useful for defining trade-offs at the phytoplankton community level (Follows \& Dutkiewicz 2011), i.e. one level above the physiological 
regulation described by the present model. The $Q_{0}^{\mathrm{N}}$ estimates for Trichodesmium and the non- $\mathrm{N}_{2}$-fixing cyanobacterium Synechococcus linearis are much larger compared with the eukaryotic species. In $S$. linearis this results in somewhat higher $Q^{\mathrm{N}}$ than in the eukaryotic species shown in Fig. 4, whereas the maximum $Q^{\mathrm{N}}$ in Trichodesmium (Fig. 5) is more similar to that of the eukaryotes.

The finding that the estimates for both $\mathrm{N}$ and $\mathrm{P}$ subsistence quotas are highest for the diazotroph, even compared with the non-diazotrophic cyanobacterium Synechococcus linearis (Table 2), might be explained by the $\mathrm{N}$ and $\mathrm{P}$ requirements of the $\mathrm{N}_{2}$ fixation apparatus (Raven 2012). If so, we would expect to find lower estimates for $Q_{0}^{\mathrm{N}}$ and $Q_{0}^{\mathrm{P}}$ if Trichodesmium was grown in a high-DIN medium. In the absence of suitable observations, this topic remains a subject of speculation, which is somewhat unfortunate as varying subsistence quotas might affect our conclusions about the optimal regulation (switching) of $\mathrm{N}_{2}$ fixation.

The theoretical minimum energy requirement of $\mathrm{N}_{2}$ fixation is $16 \mathrm{~mol} \mathrm{ATP} \mathrm{mol}^{-1} \mathrm{~N}_{2}$ (Stam et al. 1987). Using a C consumption of $0.188 \mathrm{~mol} \mathrm{C} \mathrm{mol}^{-1}$ ATP during respiratory ATP generation (Raven 1984), this translates into a lower limit for $\zeta^{\mathrm{F}}$ of $1.5 \mathrm{~mol} \mathrm{C} \mathrm{mol}^{-1}$ $\mathrm{N}$. Energy requirements derived from measurements in Rhizobium range from 20 to $42 \mathrm{~mol}$ ATP $\mathrm{mol}^{-1} \mathrm{~N}_{2}$ (Stam et al. 1987), corresponding to values between 1.9 and $4 \mathrm{~mol} \mathrm{C} \mathrm{mol}^{-1} \mathrm{~N}$ for $\zeta^{\mathrm{F}}$. Großkopf \& LaRoche (2012) calculated direct costs of $\mathrm{N}_{2}$ fixation of about $2 \mathrm{~mol} \mathrm{C} \mathrm{mol}{ }^{-1} \mathrm{~N}$. The $\zeta^{\mathrm{F}}$ estimate of $2 \mathrm{~mol} \mathrm{C} \mathrm{mol}^{-1} \mathrm{~N}$ given in Table 2 , which was obtained by fitting the model to available data (Fig. 5), thus agrees with the theoretical calculation of Großkopf \& LaRoche (2012) and is close to the minimum energy requirement estimated for Rhizobium (Stam et al. 1987).

\section{INTERACTION BETWEEN $\mathbf{N}_{2}$ FIXATION AND DIN UTILISATION}

So far we have investigated the 2 extreme cases of exclusive $\mathrm{N}_{2}$ fixation or DIN utilisation $\left(f_{\mathrm{F}}=0\right.$ and $f_{\mathrm{F}}=1$ ). The effect of combining $\mathrm{N}_{2}$ fixation with DIN uptake ( $f_{\mathrm{F}}$ between 0 and 1 ) is shown in Fig. $6 \mathrm{~A}$ for parameters fitted with $f_{\mathrm{F}}=1$ to experimental data for Trichodesmium sp. (Table 2). $\mathrm{N}_{2}$ fixation can enhance growth rate only at ambient DIN concentrations below, in this case, $16.4 \mu \mathrm{mol}^{-1}$. Growth rate is essentially a monotonic function of $f_{\mathrm{F}}$, decreasing for high DIN concentrations and increasing for low DIN concentrations, and the optimal behaviour is switching between DIN utilisation and $\mathrm{N}_{2}$ fixation. A switchover nitrate concentration $\left(N_{\mathrm{so}}\right)$ can be defined where balanced growth rates for $\mathrm{N}_{2}$ fixation and DIN utilisation are equal in Eq. (12):

$$
N_{\mathrm{so}} \equiv \bar{\mu}\left(f_{\mathrm{F}}=0\right)=\bar{\mu}\left(f_{\mathrm{F}}=1\right)
$$

The data shown in Fig. 6A suggest that a simple criterion for switching between $\mathrm{N}_{2}$ fixation and DIN utilisation can be defined based on the definition of $N_{\text {so }}$ in Eq. (14). Because $V^{\mathrm{N}}=\bar{\mu} Q^{\mathrm{N}}$ for balanced growth, this is equivalent to:

$$
f_{\mathrm{F}}^{o}=\left\{\begin{array}{lll}
1 & \text { if } & \overline{V^{\mathrm{N}}}\left(f_{\mathrm{F}}=0\right)<\overline{F^{\mathrm{N}}}\left(f_{\mathrm{F}}=1\right) \\
0 & \text { if } & \overline{V^{\mathrm{N}}}\left(f_{\mathrm{F}}=0\right) \geq \overline{F^{\mathrm{N}}}\left(f_{\mathrm{F}}=1\right)
\end{array}\right.
$$

at steady state, where $f_{\mathrm{F}}^{\mathrm{o}}$ is optimal $f_{\mathrm{F}}$ and $V^{\mathrm{N}}\left(f_{\mathrm{F}}=0\right)$ is $V^{\mathrm{N}}$ as defined in Eq. (6). $N_{\mathrm{so}}$ increases with ambient phosphate concentration and irradiance (Fig. 6B). The dashed line in Fig. 6B indicates the Redfield ratio and corresponds to the switch-over DIN concentration associated with the classical view of excess $\mathrm{P}$ as a necessary requirement for $\mathrm{N}_{2}$ fixation. The switchover DIN concentrations predicted by our optimalitybased model differ substantially from those of this
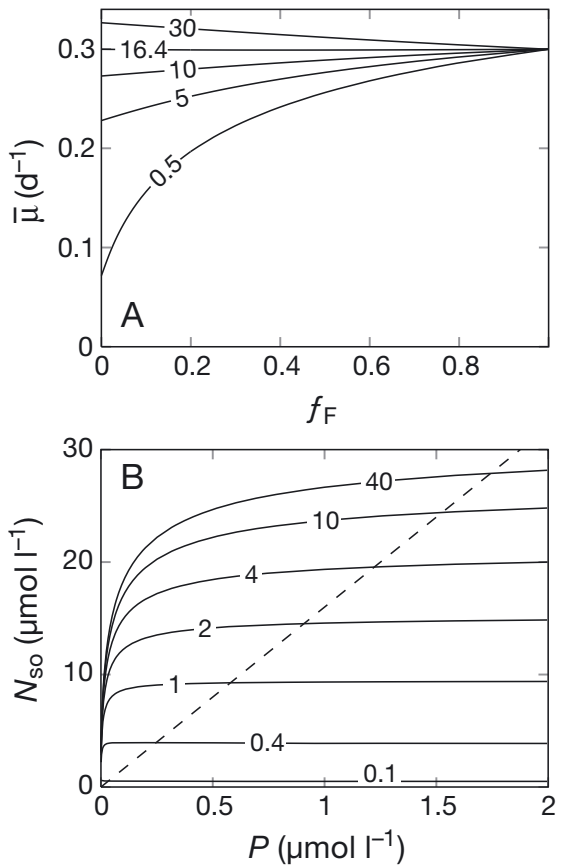

Fig. 6. (A) Growth rate $\bar{\mu}$ as a function of $f_{\mathrm{F}}$ for various dissolved inorganic nitrogen (DIN) concentrations. Line labels indicate DIN concentrations in $\mu \mathrm{mol} 1 \mathrm{l}^{-1}$ Ambient phosphate concentration $(P)$ and irradiance $(I)$ were set to $0.082 \mu \mathrm{mol}$ $\mathrm{l}^{-1}$ and $11 \mathrm{E} \mathrm{m}^{-2} \mathrm{~d}^{-1}\left(=128 \mu \mathrm{E} \mathrm{m} \mathrm{m}^{-2} \mathrm{~s}^{-1}\right.$, used by Holl \& Montoya 2005), respectively. (B) Switch-over nitrate concentration $\left(N_{\mathrm{so}}\right)$ as a function of $P$ and $I$ (line labels in $\mathrm{E} \mathrm{m}^{-2} \mathrm{~d}^{-1}$ ). Dashed line: Redfield ratio ( $\mathrm{N}: \mathrm{P}=16$ ). Parameters as in Fig. 5 
view: for low ambient DIP and high light levels, our model predicts $N_{\mathrm{so}}$ values far exceeding the Redfield equivalent of DIP, as indicated by the region above the dashed line in Fig. 6B. For high enough levels of ambient DIP and low light, the ratio of $N_{\mathrm{so}}$ to DIP is well below the Redfield ratio. The highest $N_{\text {so }}$ relative to the Redfield equivalent of DIP occurs at high irradiance and low DIP, characteristic of the surface mixed layer in stratified tropical and subtropical ocean regions. A horizontal orientation of the relationship between $N_{\text {so }}$ and DIP indicates that $N_{\text {so }}$ varies essentially independently of DIP, which occurs for moderate to high DIP and low light in Fig. 6B. The rather high switch-over concentrations at high irradiance shown in Fig. 6 indicate that $\mathrm{N}_{2}$ fixation can be the optimal choice even with a high ambient DIN concentration, as long as sufficient (light-)energy is available.

When adding $\mathrm{NO}_{3}^{-}$at 1 and $10 \mu \mathrm{mol} \mathrm{l}^{-1}$ to exponentially growing Trichodesmium cultures without detectable DIN, Mulholland et al. (2001) reported that only the addition of $10 \mu \mathrm{mol} \mathrm{l}^{-1} \mathrm{NO}_{3}^{-}$suppressed $\mathrm{N}_{2}$ fixation. Mulholland et al. (2001) employed a lower light intensity $\left(\approx 3 \mathrm{E} \mathrm{m}^{-2} \mathrm{~d}^{-1}\right)$ than that used for Fig. 6A, and the strong dependence of $N_{\mathrm{so}}$ on irradiance (Fig. 6B) implies that their observed (in)sensitivity of $\mathrm{N}_{2}$ fixation to $\mathrm{NO}_{3}^{-}$addition is roughly in line with the behaviour predicted by Eq. (15). Similarly, de Tezanos Pinto \& Litchman (2010) observed $\mathrm{N}_{2}$ fixation in the freshwater cyanobacterium Anabaena flos-aquae with a nitrate concentration of $8 \mu \mathrm{mol} \mathrm{l}^{-1}$ in the supplied growth medium, whereas a nitrate concentration of $64 \mathrm{\mu mol} \mathrm{l}^{-1}$ completely suppressed $\mathrm{N}_{2}$ fixation at light intensities of 1.3 and $8.6 \mathrm{E} \mathrm{m}^{-2} \mathrm{~d}^{-1}$ and a phosphate concentration of $2 \mu \mathrm{mol} \mathrm{l^{-1 }}$. Since the switch-over DIN concentrations at $p=2 \mu \mathrm{mol} \mathrm{l}^{-1}$ lie between 8 and $64 \mu \mathrm{mol} \mathrm{l}^{-1}$ for both light intensities (Fig. 6B), this behaviour appears to concur with our model prediction.

Holl \& Montoya (2005) found that $\mathrm{NO}_{3}^{-}$uptake by Trichodesmium did reduce $\mathrm{N}_{2}$ fixation also at low initial nitrate concentrations ( 0.5 to $5 \mu \mathrm{mol} \mathrm{l}^{-1}$ ), but this behaviour resulted in a marked reduction in growth rate compared with pure $\mathrm{N}_{2}$ fixation. They noted that growth rates comparable to those obtained with pure $\mathrm{N}_{2}$ fixation $\left(0.3 \mathrm{~d}^{-1}\right.$ in their experiment) were achieved only with initial nitrate concentrations upward of $7 \mu \mathrm{mol} \mathrm{l} \mathrm{l}^{-1}$. Eq. (12) reproduces this behaviour if $f_{\mathrm{F}}$ is small in the presence of DIN (Fig. 6A).

Single pulses of nitrate were utilised regardless of initial concentrations in the experiments of Mulholland et al. (2001) and Holl \& Montoya (2005), but only when added before the onset of the light

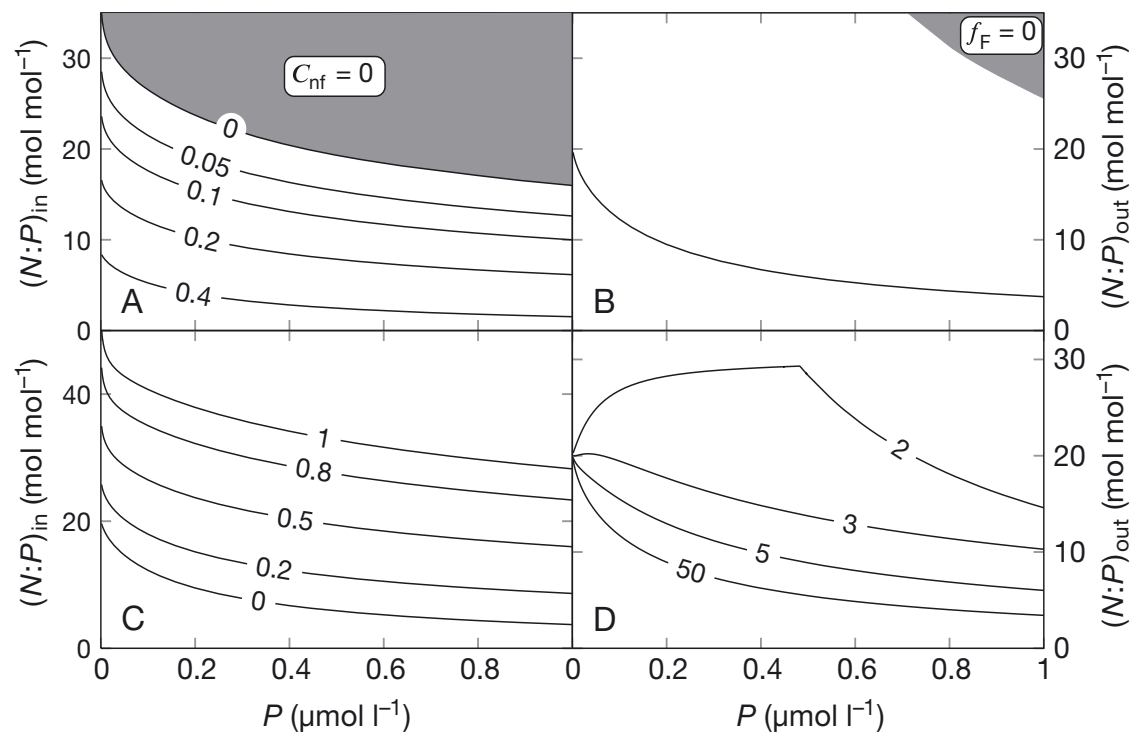

Fig. 7. Competition between $\mathrm{N}_{2}$-fixing Trichodesmium and T. fluviatilis in a simulated chemostat at steady state. (A) Ratio of Trichodesmium and diatom biomass (line labels) as a function of ambient dissolved inorganic phosphorus (DIP) concentration ( $P$ ) and dissolved inorganic nitrogen (DIN):DIP supply ratio, $(N: P)_{\text {in }}$ grown at $I=20 \mathrm{E} \mathrm{m}^{-2} \mathrm{~d}^{-1}$. Trichodesmium is outcompeted by the diatom in the shaded region above the 0 -line. $C_{\mathrm{nf}}$ : POC concentration of Trichodesmium. (B) Ambient DIN:DIP ratio in the growth chamber, $(N: P)_{\text {out, }}$ in the region below the 0-line in A. The shaded area in the top-right corner of $\mathrm{B}$ indicates where $\mathrm{N}_{2}$ fixation is not feasible according to Eq. (15). (C) Maximum $(N: P)_{\text {in }}$ above which Trichodesmium is outcompeted by the diatom for various ratios of particulate (POP) over total $\mathrm{P}, \mathrm{POP} /(\mathrm{POP}+P$ ) (line labels). Equal DIP and POP concentrations (line label 0.5) correspond to the 0 -line in (A). (D) Ambient DIN:DIP ratio $(N: P)$ for different light levels (line labels in $\left.\mathrm{E} \mathrm{m}^{-2} \mathrm{~d}^{-1}\right)$ with POP/(POP $+P)=0.5$. The diatom is outcompeted by non- $\mathrm{N}_{2}$-fixing $\left(f_{\mathrm{F}}=0\right)$ Trichodesmium to the right of the bend at the lowest light level 
period (Mulholland et al. 2001). One explanation could be that nitrogenase can be present and active only during certain times of the day (Mulholland et al. 2001), outside of which nitrate utilisation would not interfere with $\mathrm{N}_{2}$ fixation. This would imply an upper limit for the daily-mean $f_{\mathrm{F}}$ that is significantly less than 1. Since the nitrate was supplied as a single pulse, this behaviour could also be interpreted as a transient response serving to probe ambient DIN concentration in order to determine the feasibility of DIN utilisation. This interpretation would be in line with the finding that $\mathrm{N}_{2}$ fixation is suppressed more strongly by continuous than by shortterm exposure to elevated DIN concentrations (Knapp 2012).

\section{COMPETITION BETWEEN ORDINARY AND DIAZOTROPHIC PHYTOPLANKTON}

The response of the switch-over nitrate concentration to ambient phosphate concentration reveals the counter-intuitive result that $\mathrm{N}_{2}$ fixation may be most advantageous over DIN utilisation at low phosphate concentrations, particularly under high light (Fig. 6B). In order to examine the relationship between DIN and DIP concentrations and the ecological niche for $\mathrm{N}_{2}$ fixation, chemostat simulations were set up where $\mathrm{N}_{2}$-fixing Trichodesmium compete against a diatom (Fig. 7, Appendix 2). The competition simulations enforce identical net growth rates (equal to the dilution rate of the chemostat) of ordinary and diazotrophic phytoplankton as a condition of coexistence. In order to mimic the effect of remineralisation, the $\mathrm{N}$ fixed by the diazotrophs is added to the growth chamber as the cells are washed out (Appendix 2).

The decline in $\left(\mathrm{N}_{2}\right.$-fixing) Trichodesmium relative to the diatom with increasing $\mathrm{N}: \mathrm{P}$ supply ratio $(N: P)_{\text {in }}$ shown in Fig. 7A is expected. However, $\mathrm{N}_{2}$ fixation is favoured relative to diatom growth at lower supplied nutrient concentrations if $(N: P)_{\text {in }}$ is held constant. Hence we conclude that low DIP is relatively more beneficial than low DIN for diazotroph growth compared with diatom growth at low nutrient concentrations. The coexistence of diazotrophs and ordinary phytoplankton in this setup requires identical growth rates, which, for a given light level, must be uniquely determined by the ambient DIP concentration. Consequently, the residual ambient DIN:DIP ratio $(N: P)_{\text {out }}$ becomes a unique function of light and DIP concentration. Thus, unless Trichodesmium is outcompeted by the diatom, the DIN concentration in the growth chamber $(N)$ becomes independent of $(N: P)_{\text {in }}$. The relationship between $(N: P)_{\text {in }}$ and DIN: DIP in the growth chamber (Fig. 7B) can be calculated from the ratio of particulate organic phosphorus (POP) and total $\mathrm{P}\left(r_{\mathrm{P}}\right)$ and the ratio of diazotrophic and diatom biomass $\left(r_{\mathrm{C}}\right)$ :

$$
(N: P)_{\text {in }}\left(r_{\mathrm{p}}, r_{\mathrm{C}}\right)=\left(1-r_{\mathrm{P}}\right) \frac{N}{P}+r_{\mathrm{P}} \frac{Q_{\mathrm{o}}^{\mathrm{N}}-r_{\mathrm{C}} Q_{\mathrm{nf}}^{\mathrm{N}}}{Q_{\mathrm{o}}^{\mathrm{P}}-Q_{\mathrm{nf}}^{\mathrm{P}}}
$$

where the subscripts ' $\mathrm{o}$ ' and ' $\mathrm{nf}$ ' refer to ordinary and diazotrophic phytoplankton, respectively. $(N: P)_{\text {in }} \geq$ $(N: P)_{\text {in }}\left(r_{\mathrm{C}}=0\right)$ implies competitive exclusion of the diazotroph (Fig. 7C). The greater the fraction of $\mathrm{P}$ bound in the organisms, the larger the range in $(N: P)_{\text {in }}$ for which DIN:DIP is constant for any given combination of irradiance and ambient DIP concentration. Therefore, a community of diatoms and $\mathrm{N}_{2}$ fixers could be viewed as a biotic buffer controlling ambient DIN:DIP ratios, whose strength depends on the fraction of $\mathrm{P}$ absorbed in the living biomass.

The effect of light intensity on ambient DIN:DIP ratio in the presence of $\mathrm{N}_{2}$ fixation is shown in Fig. 7D. Interestingly, ambient DIN:DIP declines with increasing irradiance, contrary to the expectation that energy-intensive $\mathrm{N}_{2}$ fixation should be relatively more competitive under high-light conditions. For light levels typical for the surface ocean, DIN:DIP ratios close to or exceeding Redfield proportions are only achieved at low ambient phosphate concentrations. Another surprising prediction of our model is the competitive advantage of non- $\mathrm{N}_{2}$-fixing diazotrophs over ordinary phytoplankton at low irradiance (Fig. 7D). The low-light behaviour might not be overly significant, as Trichodesmium regulates its buoyancy by means of gas vacuoles and usually lives close to the surface. This result is in line, however, with the observation by de Tezanos Pinto \& Litchman (2010) that Anabaena flos-aquae (which also did not fix $\mathrm{N}_{2}$ in this case) dominated green algae under low light $\left(1.3 \mathrm{E} \mathrm{m}^{-2} \mathrm{~d}^{-1}\right)$ but was essentially outcompeted by green algae at $8.6 \mathrm{E} \mathrm{m}^{-2} \mathrm{~d}^{-1}$ when the DIN:DIP supply ratio was high (32).

\section{DISCUSSION}

Our model of phytoplankton growth and diazotrophy is based on a clear definition of the physiological roles of N, P, and light, according to the chain-model concept (Ågren 2004). This approach provides a common framework for simulating both ordinary and diazotrophic phytoplankton, which appears to concur with major patterns in diazotroph behaviour. Hence the model should be well suited to investigate the 

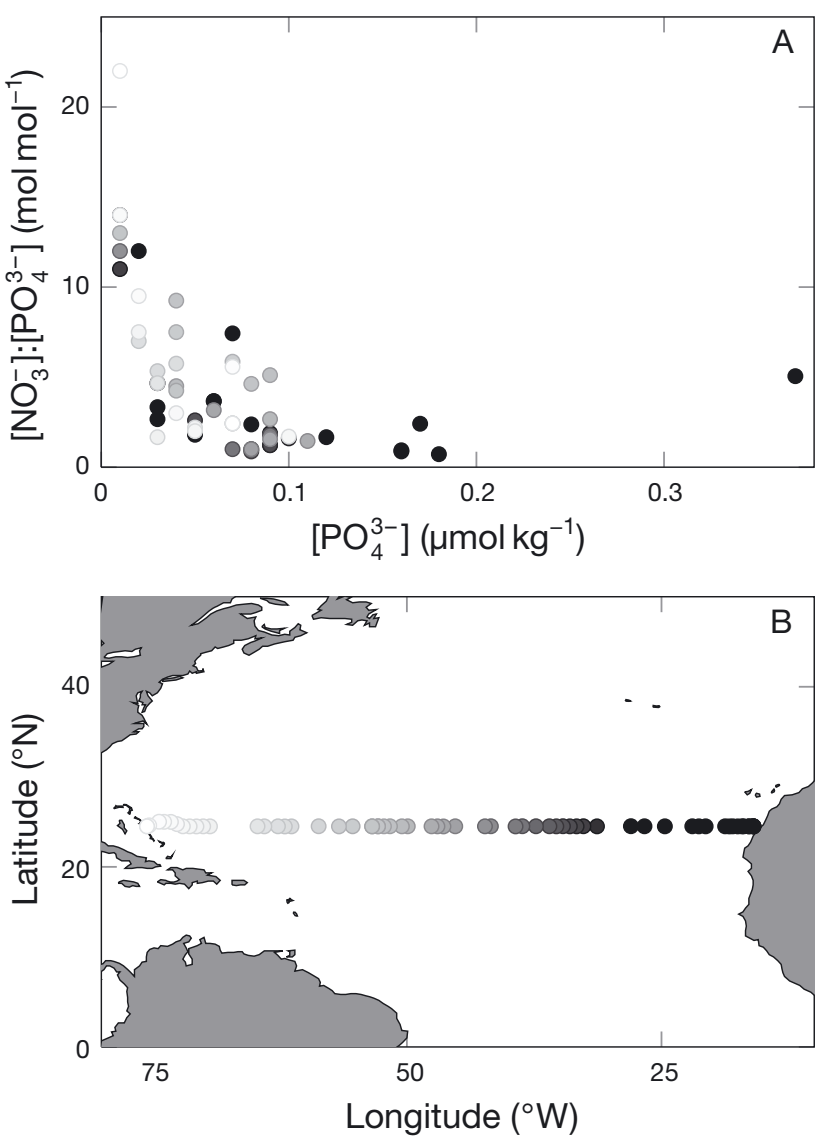

Fig. 8. (A) Ratio of ambient $\mathrm{NO}_{3}^{-}$and $\mathrm{PO}_{4}^{3-}$ concentrations vs. $\mathrm{PO}_{4}^{3-}$ concentration and (B) station locations for observations in the upper $20 \mathrm{~m}$ from the WOCE A05 transect (Millero et al. 2000). Gray shades associate data with station locations. Shown are all data flagged as acceptable by the original investigators

competition between both phytoplankton types for light and phosphate. Differences in cell quotas reflect the different physiological organisation related to the $2 \mathrm{~N}$-acquisition strategies of diazotrophic and non-diazotrophic phytoplankton. The most important model predictions, however, are the competitive abilities for light and phosphate emerging from the interaction between the cell quotas and resource $(\mathrm{C}, \mathrm{N}$, and P) acquisition (Fig. 7).

The effect of iron on the competition between diazotrophs and ordinary phytoplankton remains somewhat unclear (Sañudo-Wilhelmy et al. 2001). Iron undoubtedly affects $\mathrm{N}_{2}$ fixation as nitrogenase, the enzyme catalysing $\mathrm{N}_{2}$ fixation, does have a high iron content. Accordingly, Moore et al. (2009) invoked iron limitation of $\mathrm{N}_{2}$ fixation in the South Atlantic because they could not link $\mathrm{N}_{2}$ fixation to the observed pattern of excess P. However, the enzyme complex involved in nitrate reduction in ordinary phytoplankton also contains much iron, implying that both phytoplankton types may be similarly affected by iron limitation. In the absence of unequivocal laboratory observations, we conclude that this remains an open question.

The strong coupling between $(N: P)_{\text {out }}$ and DIP concentration shown in Fig. 7B,D implies that a community consisting of both ordinary and diazotrophic phytoplankton could exert relatively strong biotic control on the emerging surface DIN:DIP ratio and decouple $(N: P)_{\text {out }}$ from the supply DIN:DIP ratio. If this was the case, one might expect to find evidence for such a decoupling in data from field investigations. The subtropical North Atlantic might be an appropriate place to look for such a phenomenon as its surface waters are oligotrophic to ultra-oligotrophic, well lit, warm, iron replete, and only relatively weakly influenced by waters of more eutrophic origin, and $\mathrm{N}_{2}$ fixation does occur there (Kähler et al. 2010, Mills \& Arrigo 2010).

In spite of some scatter, we indeed found a relationship between DIP and the DIP:DIN ratio along a transect in the subtropical North Atlantic (Fig. 8) that qualitatively resembles our model predictions shown in Fig. 7B. This is not to say that the predicted relationship between ambient DIN:DIP and DIP concentration shown in Fig. 7B is the only interpretation of the pattern shown in Fig. 8A. While this pattern could, in fact, result from independent log-normal random distributions of DIN and DIP concentrations with the same means and variances as in the observations, it is clearly inconsistent with a Redfield coupling of $\mathrm{N}$ and P. However, the (local) biotic control of surface ambient DIN:DIP ratio predicted by our model (Fig. 7B) could explain both the decoupling and the systematic deviation (the mean DIN:DIP ratio in these observations is about 5) from the Redfield ratio.

While the simulated phytoplankton behaviour appears broadly consistent with laboratory experiments (Figs. 4 \& 5), which adds confidence to the model predictions, some of them are counter to the assumptions and conclusions of current state-of-the art biogeochemical models (e.g. Moore \& Doney 2007, Schmittner et al. 2008). Our main predictions are as follows:

(1) The optimal strategy for facultative diazotrophy is a switch between $\mathrm{N}_{2}$ fixation and DIN uptake (Fig. 6). If this switching reasonably represents diazotroph behaviour in the surface ocean, this prediction could help to reconcile the apparent discrepancy between the lack of significant DIN uptake in field observations (Orcutt et al. 2001) on the one hand, and the ability of diazotrophs to utilise DIN as demonstrated in laboratory experiments (Mulholland et al. 2001, Holl \& Montoya 2005, de Tezanos Pinto \& Litchman 2010) on the other hand. 
(2) A rather high chlorophyll-specific light absorption coefficient $\alpha$ was required for Trichodesmium, compared with the ordinary phytoplankton species in Table 2, in order to obtain a good agreement with the observations shown in Figs. 4 \& 5. A high value of $\alpha$ could be interpreted as the result of an adaptation to the high energy requirement of $\mathrm{N}_{2}$ fixation and implies that (non- $\mathrm{N}_{2}$-fixing) diazotrophs could dominate over ordinary phytoplankton under low-light, high-N conditions. This model prediction seems clearly at odds with what is generally considered as the ecological niche of diazotrophs. However, this is exactly what was observed by de Tezanos Pinto \& Litchman (2010).

(3) The strong negative relationship between N:P supply ratio and relative biomass contribution of diazotrophs (Fig. 7A) appears to concur largely with the canonical view of $\mathrm{N}_{2}$ fixation being favoured by excess P. However, there is more to the story. Both the modelled switch-over behaviour (Fig. 6) and the results of the competition experiments (Fig. 7) predict that, for any given DIN:DIP supply ratio, $\left(\mathrm{N}_{2}\right.$-fixing) diazotrophs have a competitive advantage at lowphosphate and high-light conditions, which can be understood as a consequence of the interaction of $\mathrm{N}$ and $\mathrm{P}$ in the chain model: ordinary phytoplankton must allocate an increasing fraction of their cellular $\mathrm{N}$ to $\mathrm{N}$ acquisition, and hence an ever smaller fraction is available for DIP uptake as DIN concentrations diminish, which is not the case for diazotrophs, as $\mathrm{N}_{2}$ gas availability never limits $\mathrm{N}_{2}$ fixation ( $F^{\mathrm{N}}$ in Eq. 11). Thus, diazotrophs can allocate relatively more $\mathrm{N}$ to the P-uptake machinery than ordinary phytoplankton in the presence of low nutrient concentrations. In consequence, ordinary phytoplankton experience a strong colimitation by DIN and DIP availability (Eqs. 7 \& 8) under oligotrophic conditions, whereas diazotrophs are only $\mathrm{P}$ limited. Even if their nutrient affinity $\left(A_{0}\right)$ is lower than that of their competitors (Table 2), diazotrophs suffer less from nutrient limitation under oligotrophic conditions, where they compete successfully against ordinary phytoplankton even in the presence of high ambient DIN:DIP ratios (e.g. Monteiro et al. 2010). Maybe somewhat counter-intuitively, it follows that the ability to fix $\mathrm{N}$ comes along with superior phosphate competition capabilities. This result is consistent with observations of a positive relationship between $\mathrm{P}$ stress and $\mathrm{N}_{2}$ fixation in both marine (Hynes et al. 2009) and terrestrial environments (Houlton et al. 2008). The ability to utilise dissolved organic P (DOP) has been suggested to further strengthen the competitive advantage of diazotrophs (Dyhrman et al. 2006, Houl- ton et al. 2008). However, the importance of this mechanism is unclear as DOP utilisation is also widespread among eukaryotic phytoplankton (e.g. Cembella et al. 1982, Raven 2012).

We conclude that a revision is warranted of the view, put forward, for example, by Deutsch et al. (2007), that diazotrophy is simply favoured by excess $\mathrm{P}$ in the surface ocean, relative to the Redfield equivalent (1/16) of the DIN concentration.

Acknowledgements. This work is a contribution of the Sonderforschungsbereich 754 'Climate-Biogeochemistry Interactions in the Tropical Ocean' (www.sfb754.de), which is funded by the German Science Foundation (DFG) and of the Seventh Framework Programme (FP7) project 'Ocean Strategic Services beyond 2015' (www.oss2015.eu). We are grateful for comments by K. W. Wirtz, M. Moore, and 2 anonymous reviewers.

\section{LITERATURE CITED}

Agawin NSR, Rabouille S, Veldhuis MJW, Servatius L, Hol S, van Overzee HMJ, Huisman J (2007) Competition and facilitation between unicellular nitrogen-fixing cyanobacteria and non-nitrogen-fixing phytoplankton species. Limnol Oceanogr 52:2233-2248

Ågren GI (2004) The C: N: P stoichiometry of autotrophstheory and observations. Ecol Lett 7:185-191

Altabet MA (2007) Constraints on oceanic N balance/imbalance from sedimentary ${ }^{15} \mathrm{~N}$ records. Biogeosciences 4 : 75-86

Altabet MA, Higginson MJ, Murray DW (2002) The effect of millennial-scale changes in arabian sea denitrification on atmospheric $\mathrm{CO}_{2}$. Nature 415:159-162

Armstrong RA (2008) Nutrient uptake rate as a function of cell size and surface transporter density: a Michaelis-like approximation to the model of Pasciak and Gavis. DeepSea Res I 55:1311-1317

Berman-Frank I, Quigg A, Finkel ZV, Irwin AJ, Haramaty L (2007) Nitrogen-fixation strategies and Fe requirements in cyanobacteria. Limnol Oceanogr 52:2260-2269

> Bissett WP, Walsh JJ, Dieterle DA, Carder KL (1999) Carbon cycling in the upper waters of the Sargasso Sea: I. Numerical simulation of differential carbon and nitrogen fluxes. Deep-Sea Res I 46:205-269

Bougaran G, Bernard O, Sciandra A (2010) Modeling continuous cultures of microalgae colimited by nitrogen and phosphorus. J Theor Biol 265:443-454

Bruggeman J, Kooijman SALM (2007) A biodiversityinspired approach to aquatic ecosystem modeling. Limnol Oceanogr 52:1533-1544

Capone DG, Burns JA, Montoya JP, Subramaniam A and others (2005) Nitrogen fixation by Trichodesmium spp.: an important source of new nitrogen to the tropical and subtropical North Atlantic Ocean. Global Biogeochem Cycles 19:GB2024, doi:10.1029/2004GB002331

> Cembella AD, Antia NJ, Harrison PJ (1982) The utilization of inorganic and organic phosphorus compounds as nutrients by eukaryotic microalgae: a multidisciplinary perspective: part 1. Crit Rev Microbiol 10:317-391 
de Tezanos Pinto P, Litchman E (2010) Interactive effects of $\mathrm{N}: \mathrm{P}$ ratios and light on nitrogen-fixer abundance. Oikos 119:567-575

> Deutsch C, Weber T (2012) Nutrient ratios as a tracer and driver of ocean biogeochemistry. Annu Rev Mar Sci 4: 113-141

> Deutsch C, Sarmiento JL, Sigman DM, Gruber N, Dunne JP (2007) Spatial coupling of nitrogen inputs and losses in the ocean. Nature 445:163-167

$>$ Devol AH (2008) Denitrification including anammox. In: Capone DG, Bronk DA, Mulholland MR, Carpenter EJ (eds) Nitrogen in the marine environment, 2nd edn. Elsevier Academic, Amsterdam, p 263-301

> Dietze H, Oschlies A, Kähler P (2004) Internal-waveinduced and double-diffusive nutrient fluxes to the nutrient-consuming surface layer in the oligotrophic subtropical North Atlantic. Ocean Dyn 54:1-7

> Dyhrman ST, Chappell PD, Haley ST, Moffett JW, Orchard ED, Waterbury JB, Webb EA (2006) Phosphonate utilization by the globally important marine diazotroph Trichodesmium. Nature 439:68-71

> Falcón LI, Pluvinage S, Carpenter EJ (2005) Growth kinetics of marine unicellular $\mathrm{N}_{2}$-fixing cyanobacterial isolates in continuous culture in relation to phosphorus and temperature. Mar Ecol Prog Ser 285:3-9

Falkowski PG (1997) Evolution of the nitrogen cycle and its influence on the biological sequestration of $\mathrm{CO}_{2}$ in the ocean. Nature 387:272-275

Fennel K, Spitz YH, Letelier RM, Abbott MR, Karl DM (2002) A deterministic model for $\mathrm{N}_{2}$ fixation at stn. ALOHA in the subtropical North Pacific Ocean. Deep-Sea Res II 49: 149-174

> Follows MJ, Dutkiewicz S (2011) Modeling diverse communities of marine microbes. Annu Rev Mar Sci 3:427-451

Geider RJ, MacIntyre HL, Kana TM (1998) A dynamic regulatory model of phytoplanktonic acclimation to light, nutrients, and temperature. Limnol Oceanogr 43:679-694

> Großkopf T, LaRoche J (2012) Direct and indirect costs of dinitrogen fixation in Crocosphaera watsonii WH8501 and possible implications for the nitrogen cycle. Front Microbiol 3:236

Gruber N (2004) The dynamics of the marine nitrogen cycle and its influence on atmospheric $\mathrm{CO}_{2}$ variations. In: Follows M, Oguz T (eds) The ocean carbon cyle and climate. Kluwer, Dordrecht, p 97-148

> Hansell DA, Bates NR, Olson DB (2004) Excess nitrate and nitrogen fixation in the North Atlantic Ocean. Mar Chem 84:243-265

Hawser SP, O'Neil JM, Roman MR, Codd GA (1992) Toxicity of blooms of the cyanobacterium-trichodesmium to zooplankton. J Appl Phycol 4:79-86

> Healey FP (1985) Interacting effects of light and nutrient limitation on the growth rate of Synechococcus linearis (Cyanophyceae). J Phycol 21:134-146

> Holl CM, Montoya JP (2005) Interactions between nitrate uptake and nitrogen fixation in continuous cultures of the marine diazotroph Trichodesmium (cyanobacteria). J Phycol 41:1178-1183

- Holl CM, Montoya JP (2008) Diazotrophic growth of the marine cyanobacterium Trichodesmium IMS101 in continuous culture: effects of growth rate on $\mathrm{N}_{2}$-fixation rate, biomass, and C:N:P stoichiometry. J Phycol 44:929-937

> Hood RR, Bates NR, Capone DG, Olson DB (2001) Modeling the effect of nitrogen fixation on carbon and nitrogen fluxes at BATS. Deep-Sea Res II 48:1609-1648
Houlton BZ, Wang YP, Vitousek PM, Field CB (2008) A unifying framework for dinitrogen fixation in the terrestrial biosphere. Nature 454:327-330

Hynes AM, Chappell PD, Dyhrman ST, Doney SC, Webb EA (2009) Cross-basin comparison of phosphorus stress and nitrogen fixation in Trichodesmium. Limnol Oceanogr 54:1438-1448

Kähler P, Oschlies A, Dietze H, Koeve W (2010) Oxygen, carbon, and nutrients in the oligotrophic eastern subtropical North Atlantic. Biogeosciences 7:1143-1156

Knapp AN (2012) The sensitivity of marine $\mathrm{N}_{2}$ fixation to dissolved inorganic nitrogen. Front Microbiol 3:374

- Langlois RJ, LaRoche J, Raab PA (2005) Diazotrophic diversity and distribution in the tropical and subtropical Atlantic Ocean. Appl Environ Microbiol 71:7910-7919

LaRoche J, Breitbarth E (2005) Importance of the diazotrophs as a source of new nitrogen in the ocean. J Sea Res 53:67-91

Laws EA, Bannister TT (1980) Nutrient and light limited growth of Thalassiosira fluviatilis in continuous culture, with implications for phytoplankton growth in the ocean. Limnol Oceanogr 25:457-473

> Lenton TM, Klausmeier CA (2007) Biotic stoichiometric controls on the deep ocean N:P ratio. Biogeosciences 4: 353-367

Millero FJ, Fiol S, Campbell DM, Parilla G (2000) Carbon dioxide, hydrographic, and chemical data obtained during the R/V Hespérides cruise in the Atlantic Ocean. In: Allison LJ, Kozyr A (eds) (WOCE section A5, July 14-August 15, 1992: Ornl/cdiac-125, ndp-074). US Department of Energy Carbon Dioxide Information Analysis Center, Oak Ridge National Laboratory, Oak Ridge, TN

Mills MM, Arrigo KR (2010) Magnitude of oceanic nitrogen fixation influenced by the nutrient uptake ratio of phytoplankton. Nat Geosci 3:412-416

Mills MM, Ridame C, Davey M, LaRoche J, Geider RJ (2004) Iron and phosphorus co-limit nitrogen fixation in the eastern tropical North Atlantic. Nature 429:292

Monteiro FM, Follows MJ, Dutkiewicz S (2010) Distribution of diverse nitrogen fixers in the global ocean. Global Biogeochem Cycles 24:GB3017, doi:10.1029/2009GB003731

Monteiro FM, Dutkiewicz S, Follows MJ (2011) Biogeographical controls on the marine nitrogen fixers. Global Biogeochem Cycles 25:GB2003, doi:10.1029/2010GB 003902

Moore JK, Doney SC (2007) Iron availability limits the ocean nitrogen inventory stabilizing feedbacks between marine denitrification and nitrogen fixation. Global Biogeochem Cycles 21:GB2001, doi:10.1029/2006GB002762

Moore CM, Mills MM, Achterberg EP, Geider RJ and others (2009) Large-scale distribution of Atlantic nitrogen fixation controlled by iron availability. Nat Geosci 2:867-871

> Mulholland MR, Bernhardt PW (2005) The effect of growth rate, phosphorus concentration, and temperature on $\mathrm{N}_{2}$ fixation, carbon fixation, and nitrogen release in continuous cultures of Trichodesmium IMS101. Limnol Oceanogr 50:839-849

> Mulholland MR, Capone DG (1999) Nitrogen fixation, uptake and metabolism in natural and cultured populations of Trichodesmium spp. Mar Ecol Prog Ser 188: $33-49$

> Mulholland MR, Ohki K, Capone DG (2001) Nutrient controls on nitrogen uptake and metabolism by natural populations and cultures of Trichodesmium (Cyanobacteria). J Phycol 37:1001-1009 
Neumann T (2000) Towards a 3D-ecosystem model of the Baltic Sea. J Mar Syst 25:405-419

Nixon PJ, Michoux F, Yu J, Boehm M, Komenda J (2010) Recent advances in understanding the assembly and repair of Photosystem II. Ann Bot 106:1-16

Orcutt KM, Lipschultz F, Gundersen K, Arimoto R, Michaels AF, Knap AH, Gallon JR (2001) A seasonal study of the significance of $\mathrm{N}_{2}$ fixation by Trichodesmium spp. at the Bermuda Atlantic Time-series Study (BATS) site. Deep-Sea Res II 48:1583-1608

Pahlow M (2005) Linking chlorophyll-nutrient dynamics to the Redfield N:C ratio with a model of optimal phytoplankton growth. Mar Ecol Prog Ser 287:33-43

Pahlow M, Oschlies A (2009) Chain model of phytoplankton P, N and light colimitation. Mar Ecol Prog Ser 376:69-83

Pahlow M, Oschlies A (2013) Optimal allocation backs Droop's cell-quota model. Mar Ecol Prog Ser 473:1-5

Pahlow M, Vézina AF, Casault B, Maass H, Malloch L, Wright DG, Lu Y (2008) Adaptive model of plankton dynamics for the North Atlantic. Prog Oceanogr 76:151-191

Quigg A, Beardall J (2003) Protein turnover in relation to maintenance metabolism at low photon flux in two marine microalgae. Plant Cell Environ 26:693-703

Rabouille S, Staal M, Stal LJ, Soetaert K (2006) Modeling the dynamic regulation of nitrogen fixation in the cyanobacterium Trichodesmium sp. Appl Environ Microbiol 72:3217-3227

Raven JA (1984) Dark respiration. In: Raven JA (ed) Energetics and transport in aquatic plants, MBL Lectures in Biology Vol 4. Liss, New York, NY, p 253-317

Raven JA (2012) Protein turnover and plant RNA and phosphorus requirements in relation to nitrogen fixation. Plant Sci 188-189:25-35

Redfield AC (1958) The biological control of chemical factors in the environment. Am Sci 46:205-221

Rhee GY (1974) Phosphate uptake under nitrate limitation by Scenedesmus sp. and its ecological implications. J Phycol 10:470-475

Rhee GY (1978) Effects of N:P atomic ratios and nitrate limitation on algal growth, cell compositions, and nitrate uptake. Limnol Oceanogr 23:10-25

Sañudo-Wilhelmy SA, Kustka AB, Gobler CJ, Hutchins DA and others (2001) Phosphorus limitation of nitrogen fixation by Trichodesmium in the central Atlantic Ocean. Nature 411:66-69

Schmittner A, Oschlies A, Matthews HD, Galbraith ED (2008) Future changes in climate, ocean circulation, eco- systems, and biogeochemical cycling simulated for a business-as-usual $\mathrm{CO}_{2}$ emission scenario until year 4000 AD. Global Biogeochem Cycles 22:GB1013, doi:10.1029/ 2007GB002953

> Shuter B (1979) A model of physiological adaptation in unicellular algae. J Theor Biol 78:519-552

> Smith SL, Yamanaka Y (2007) Optimization-based model of multinutrient uptake kinetics. Limnol Oceanogr 52: 1545-1558

> Smith SL, Pahlow M, Merico A, Wirtz KW (2011) Optimalitybased modeling of planktonic organisms. Limnol Oceanogr 56:2080-2094

Sohm JA, Webb EA, Capone DG (2011) Emerging patterns of marine nitrogen fixation. Nat Rev Microbiol 9:499-508

Stam H, Stouthamer AH, van Verseveld HW (1987) Hydrogen metabolism and energy costs of nitrogen fixation. FEMS Microbiol Rev 46:73-92

Sterner RW, Elser JJ (2002) Ecological stoichiometry: the biology of elements from molecules to the biosphere. Princeton University Press, Princeton, NJ

Terry KL, Hirata J, Laws EA (1983) Light-limited growth of two marine strains of the marine diatom Phaeodactylum tricornutum Bohlin: chemical composition, carbon partitioning and the diel periodicity of physiological processes. J Exp Mar Biol Ecol 68:209-227

Terry KL, Hirata J, Laws EA (1985) Light-, nitrogen-, and phosphorus-limited growth of Phaeodactylum tricornutum Bohlin strain TFX-1: chemical composition, carbon partitioning, and the diel periodicity of physiological processes. J Exp Mar Biol Ecol 86:85-100

Vavilin D, Vermaas W (2007) Continuous chlorophyll degradation accompanied by chlorophyllide and phytol reutilization for chlorophyll synthesis in Synechocystis sp. PCC 6803. Biochim Biophys Acta 1767:920-929

> Weber T, Deutsch C (2012) Oceanic nitrogen reservoir regulated by plankton diversity and ocean circulation. Nature 489:419-422

> Wirtz KW, Pahlow M (2010) Dynamic chlorophyll and nitrogen:carbon regulation in algae optimizes instantaneous growth rate. Mar Ecol Prog Ser 402:81-96

- Yoshikawa C, Coles VJ, Hood RR, Capone DG, Yoshida N (2013) Modeling how surface nitrogen fixation influences subsurface nutrient patterns in the North Atlantic. J Geophys Res Oceans 118:2520-2534

> Zehr JP, Ward BB (2002) Nitrogen cycling in the ocean: New perspectives on processes and paradigms. Appl Environ Microbiol 68:1015-1024 
Appendix 1. Optimal chlorophyll regulation

Chlorophyll synthesis is driven by the balance of $\mathrm{CO}_{2}$ fixation and the cost of photosynthesis incurred within the chloroplast. The cost of photosynthesis is introduced here to account for the energy requirement of the continuous turnover of chlorophyll and D1 protein during photosynthesis (Vavilin \& Vermaas 2007, Nixon et al. 2010), and is formulated as the sum of a light-dependent (proportional to the degree of light saturation, $S^{\text {I }}$, Eq. 2) and a light-independent term (proportional to the cost of chlorophyll maintenance, $R_{\mathrm{M}}^{\mathrm{chl}}$ ):

$$
R^{\mathrm{chl}}=\left(V_{0}^{C} S^{\mathrm{I}}+R_{\mathrm{M}}^{\mathrm{chl}}\right) \zeta^{\mathrm{chl}} \theta, \quad \theta=\hat{\theta}\left(1-f_{\mathrm{V}}-\frac{Q_{\mathrm{s}}^{\mathrm{N}}}{Q^{\mathrm{N}}}\right)
$$

where $\zeta^{\text {chl }}$ is the cost of photosynthesis coefficient and $\theta$ is the cellular chl:C ratio. The cost of photosynthesis is meant to cover dark-respiration costs of all metabolic activities other than nutrient uptake and assimilation (Pahlow \& Oschlies 2013). This formulation (Eq. A1) ties maintenance respiration to cellular chlorophyll content and thereby goes beyond previous phytoplankton growth models (e.g. Shuter 1979, Geider et al. 1998, Pahlow \& Oschlies 2009), which assumed constant maintenance respiration. Our new formulation links night-time respiration with daytime activity and introduces a threshold irradiance (see Eq. A5 below) for growth. Substituting Eqs. (2), (3), (4), and (A1) into Eq. (1) gives:

$$
\begin{aligned}
& \bar{\mu}=\overline{\mathscr{S}}\left(1-\frac{Q_{\mathrm{s}}^{\mathrm{N}}}{Q^{\mathrm{N}}}-f_{\mathrm{V}}\right)-\zeta^{\mathrm{N}} f_{\mathrm{V}} \hat{V}^{\mathrm{N}}, \\
& \overline{\mathscr{T}}=L_{\mathrm{d}} V_{0}^{\mathrm{C}} S^{\mathrm{I}}\left(1-\zeta^{\mathrm{chl}} \hat{\theta}\right)-R_{\mathrm{M}}^{\mathrm{chl}} \zeta^{\mathrm{chl}} \hat{\theta}
\end{aligned}
$$

where $\mathscr{A}$ is a short-hand notation containing all lightdependent terms, $L_{\mathrm{d}}$ is day length, and the overbar indicates averaging over $24 \mathrm{~h}$, in addition to the balancedgrowth assumption. Instantaneous growth rate is obtained by omitting $L_{\mathrm{d}}$ from Eq. (A2). Since $\mathscr{T}$ is independent of $Q^{N}, \hat{\theta}$ can be optimised independently of $f_{\mathrm{V}}$, which makes it relatively straightforward to determine the optimal chl:C ratio of the chloroplast $\left(\hat{\theta}^{\circ}\right)$ as the value that maximises the net balanced growth rate:

$$
\frac{\mathrm{d} \bar{\mu}}{\mathrm{d} \hat{\theta}} \stackrel{!}{=} 0 \Leftrightarrow \frac{\mathrm{d} \overline{\mathscr{T}}}{\mathrm{d} \hat{\theta}}=0
$$

$$
\begin{array}{rlr}
\Leftrightarrow \quad \hat{\theta}^{\mathrm{o}} & =\frac{1}{\zeta^{\mathrm{chl}}}+\frac{V_{0}^{\mathrm{C}}}{\alpha I}\left\{1-W_{0}\left[\left(1+\frac{R_{\mathrm{M}}^{\mathrm{chl}}}{L_{\mathrm{d}} V_{0}^{\mathrm{C}}}\right) \exp \left(1+\frac{\alpha I}{V_{0}^{\mathrm{C}} \zeta^{\mathrm{chl}}}\right)\right]\right\} & \text { if } I>I_{0}
\end{array}
$$

where $W_{0}$ is the 0 -branch of the Lambert- $W$ function and:

$$
I_{0}=\frac{\zeta^{\text {chl }} R_{\mathrm{M}}^{\mathrm{chl}}}{L_{\mathrm{d}} \alpha}
$$

is the threshold irradiance for chlorophyll synthesis.

Appendix 2. Competition simulations

The competition experiments between ordinary and diazotrophic phytoplankton are set up as static-DIP chemostat simulations, i.e. the dilution rate is adjusted to keep DIP concentration constant in the simulated growth chamber. This setup facilitates tracking the effects of ambient DIP concentration but does not affect the steady-state behaviour of the model. Diazotrophic and ordinary phytoplankton are represented by the parameters for Trichodesmium (with $f_{\mathrm{F}}=1$ ) and $T$. fluviatilis, respectively, in Table 2:

$$
\begin{aligned}
& \frac{\mathrm{d} C_{m}}{\mathrm{~d} t}=\left(\mu_{m}-D\right) C_{m} \quad m \in[\text { dia, nf }] \\
& \frac{\mathrm{d} N_{m}}{\mathrm{~d} t}=\left(V_{\mathrm{T}, m}^{\mathrm{N}}-Q_{\mathrm{m}}^{\mathrm{N}} D\right) C_{m} \\
& \frac{\mathrm{d} P_{m}}{\mathrm{~d} t}=\left(V_{m}^{\mathrm{P}}-Q_{\mathrm{m}}^{\mathrm{P}} D\right) C_{m}
\end{aligned}
$$

$$
\begin{aligned}
& \frac{\mathrm{d} P}{\mathrm{~d} t}=-\sum_{m=\text { dia,nf }} V_{m}^{\mathrm{P}} C_{m}+\left(P_{\mathrm{in}}-P\right) D \\
& \frac{\mathrm{d} N}{\mathrm{~d} t}=-V_{\text {dia }}^{\mathrm{N}}-C_{\text {dia }}+\left(N_{\text {in }}+N_{\mathrm{nf}}-N\right) D
\end{aligned}
$$

where the subscripts 'dia', 'nf', and 'in' refer to diatom, Trichodesmium, and concentrations in the inflow, respectively, and $D$ is the dilution rate. The results shown in Fig. 7 are steady-state solutions of Eqs. (A6) to (A10). The N contained in $\mathrm{N}_{2}$-fixing Trichodesmium cells washed out of the growth chamber was added back in the form of DIN by adding the term $N_{\mathrm{nf}} D$ in the rightmost term in Eq. (A10). This is equivalent to assuming full remineralisation of all washed-out phytoplankton cells at steady state. Trichodesmium and the diatom coexist across a wide range of $\mathrm{N}$ :P supply ratios in these simulations (Fig. 7A). 